Review

\title{
The Ambivalent Function of YAP in Apoptosis and Cancer
}

\author{
Xianbin Zhang *(D), Ahmed Abdelrahman, Brigitte Vollmar and Dietmar Zechner(i) \\ Institute for Experimental Surgery, Rostock University Medical Center, Schillingallee 69a, \\ 18059 Rostock, Germany; ahmed.abdelrahman@med.uni-rostock.de (A.A.); \\ brigitte.vollmar@uni-rostock.de (B.V.); dietmar.zechner@uni-rostock.de (D.Z.) \\ * Correspondence: zhangxianbin@hotmail.com; Tel.: +49-381-494-2506; Fax: +49-381-494-2502
}

Received: 12 October 2018; Accepted: 23 November 2018; Published: 27 November 2018

\begin{abstract}
Yes-associated protein, a core regulator of the Hippo-YAP signaling pathway, plays a vital role in inhibiting apoptosis. Thus, several studies and reviews suggest that yes-associated protein is a good target for treating cancer. Unfortunately, more and more evidence demonstrates that this protein is also an essential contributor of p73-mediated apoptosis. This questions the concept that yes-associated protein is always a good target for developing novel anti-cancer drugs. Thus, the aim of this review was to evaluate the clinical relevance of yes-associated protein for cancer pathophysiology. This review also summarized the molecules, processes and drugs, which regulate Hippo-YAP signaling and discusses their effect on apoptosis. In addition, issues are defined, which should be addressed in the future in order to provide a solid basis for targeting the Hippo-YAP signaling pathway in clinical trials.
\end{abstract}

Keywords: Hippo; YAP; signaling pathway; cell death; autophagy; p73; cancer; therapy

\section{Introduction to YAP and the Hippo Signaling Pathway}

Yes-associated protein (YAP) is a core component of the Hippo signaling pathway in mammals [1]. Initially, this pathway was described to control organ size [2]. However, recently it has been discovered that YAP is also involved in oncogenesis [3,4] as well as apoptosis [5-11]. Hence, YAP is considered to be an emerging target to treat cancer. In mammals, multiple proteins such as the mammalian sterile 20-like kinases (MST1 and MST2, MST1/2), the large tumor suppressor kinases (LATS1 and LATS2, LATS1/2), the yes-associated protein (YAP), the transcriptional coactivator with PDZ-binding motif (TAZ), and the TEA domain family (TEAD1-4) transcription factors are important components of the Hippo signaling pathway (Figure 1) [1,2,4]. In addition, other transcription factors such as runt-related transcription factors (RUNX) and p73 are also involved in this pathway [6,12].

It has been reported that, for example, high cellular density or stimulation of G-protein-coupled receptors can switch "ON" Hippo signaling pathway by phosphorylating MST1/2 [13,14]. Subsequently, LATS1/2 and YAP are phosphorylated, leading to YAP cytoplasmic retention (inactive) and degradation $[13,14]$. In contrast, when cells are grown under conditions of low density, this pathway is switched "OFF", YAP can translocate to the nucleus $[1,2,4,13]$. Subsequently, it interacts with TEAD transcription factors and induces the expression of several genes, such as Cyclooxygenase-2 (COX-2) [15], BIRC 5 (Survivin) [16,17], glucose-transporter 1 (Glut1) [18], and glucose-transporter 3 (Glut3) [19].

However, it also has been found that when cells suffer DNA damage stress, nuclear YAP can interacts with p73 and enhances the transcription of pro-apoptotic genes, such as p53AIP1 [5], Bax [6,20], DR5 [7], and PUMA [8]. Consistent with this bivalent effect on apoptosis, the role of YAP in cancer is also contradictive. For example, several studies demonstrated that YAP is highly expressed in 
pancreatic cancer and that high expression correlates with poor survival [21,22]. In addition, recent evidence proved that YAP promotes metastasis and proliferation of breast cancer cells $[23,24]$ and contributes to the poor metastasis-free survival of these patients [25]. Thus, these studies suggest that YAP is involved in oncogenesis. However, Yuan et al. found that YAP is barely expressed in human breast cancer tissue and can be considered to be a tumor suppressor [26]. Therefore, it seems to be context dependent, if YAP can serve as a tumor suppressor or an oncogene.

Thus, in this review, we summarized the clinical relevance of YAP for cancer pathophysiology. We also reviewed molecules, processes and drugs, which are involved in Hippo-YAP signaling and their effect on apoptosis. Finally, we defined issues which should be addressed in the future.

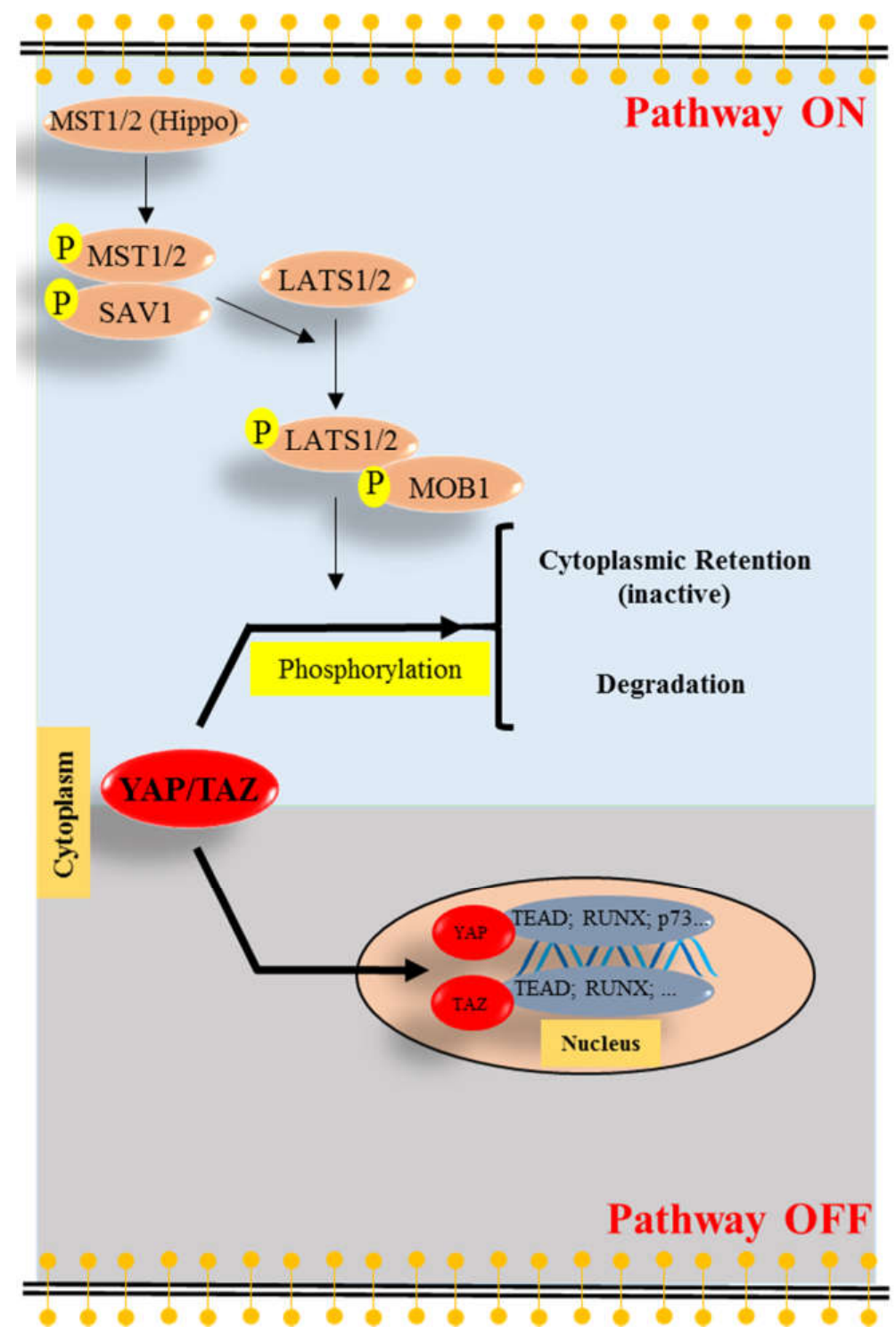

Figure 1. Components of the Hippo-YAP signaling pathway. When the pathway is switched "ON" (blue background), activated mammalian sterile 20-like kinases (MST1 and MST2, MST1/2) and Salvador homolog 1 (SAV1) phosphorylate and activate the large tumor suppressor kinases (LATS1 and LATS2, LATS1/2). The activated LATS1/2 and MOB kinase activators 1 (MOB1) phosphorylate yes-associated protein (YAP) or the transcriptional coactivator with PDZ-binding motif (TAZ), leading to YAP/TAZ cytoplasmic retention (inactive) and degradation. When the pathway is switched "OFF" (gray background), YAP/TAZ accumulates in the nucleus and forms complexes with some transcription factors such as TEA domain (TEAD) family transcription factors, runt-related transcription factors (RUNX) and p73. Arrow: Increase. 


\section{The Anti-Apoptotic Function of YAP}

\subsection{YAP Is Overexpressed in Cancer and Inhibits Apoptosis}

Most clinical studies have demonstrated that YAP is overexpressed in tumors and associated with poor survival of patients with solid tumors [21,22,27], such as lung tumors [28], pancreatic tumors [21,22,27], and colorectal tumors [29]. In addition, several studies proved that the YAP gene is amplified in cervical, ovarian, and fallopian tube cancers [30,31]. Moreover, silencing the expression of YAP gene by shRNA $[18,32,33]$ or siRNA $[15,34-48]$ could induce apoptosis (Table 1$)$. Consistent with this finding, overexpressing YAP significantly inhibited apoptosis of liver [38,49,50], pancreas [39], colorectal cancer [15,51], and lung cancer cells [52]. All these publications suggest that YAP inhibits apoptosis. This could lead to accelerated tumor growth, which might then cause poor survival of patients [53]. Thus, YAP has a pro-oncogenic function. However, Liu et al. found that YAP gene silencing failed to promote cell apoptosis in thyroid papillary carcinoma cells [54]. In addition, they demonstrated that YAP gene silencing inhibited c-Myc expression. Possibly the repression of the pro-apoptotic gene c-Myc prevented the induction of apoptosis in these cells [55]. This might explain why silencing the $Y A P$ gene failed to induce apoptosis in this study [54].

Table 1. Manipulation of YAP expression and its effect on apoptosis.

\begin{tabular}{|c|c|c|c|c|}
\hline Cancer & Method & YAP Expression & Apoptosis & PMID \\
\hline Esophagus & shRNA & \multirow{19}{*}{ Decreased } & \multirow{19}{*}{ Increased } & $27307755[32]$ \\
\hline Lung & shRNA & & & $25665005[33]$ \\
\hline Breast & shRNA & & & 28892790 [18] \\
\hline Stomach & siRNA & & & $27073556[34]$ \\
\hline Stomach & siRNA & & & 21805037 [35] \\
\hline Liver & siRNA & & & $23419361[36]$ \\
\hline Liver & siRNA & & & 27323827 [37] \\
\hline Liver & siRNA & & & 29928445 [38] \\
\hline Pancreas & siRNA & & & 27738325 [39] \\
\hline Pancreas & siRNA & & & $27669292[40]$ \\
\hline Pancreas & siRNA & & & $22396793[41]$ \\
\hline Colon/Rectum & siRNA & & & 29439714 [42] \\
\hline Colon/Rectum & shRNA & & & 29241219 [43] \\
\hline Colon/Rectum & shRNA & & & $29037225[15]$ \\
\hline Colon/Rectum & siRNA & & & 26944315 [44] \\
\hline Colon/Rectum & siRNA & & & 29512779 [45] \\
\hline Ovarian & siRNA & & & 29848699 [46] \\
\hline Prostate & siRNA & & & 26126522 [47] \\
\hline Rhabdomyosarcoma & shRNA & & & $26496700[48]$ \\
\hline Lung & cDNA & \multirow{7}{*}{ Increased } & \multirow{7}{*}{ Decreased } & 20219076 [52] \\
\hline Liver & cDNA & & & 24482231 [49] \\
\hline Liver & cDNA & & & $27359056[50]$ \\
\hline Liver & cDNA & & & 29928445 [38] \\
\hline Pancreas & cDNA & & & 27738325 [39] \\
\hline Colon/Rectum & cDNA & & & $29037225[15]$ \\
\hline Colon/Rectum & cDNA & & & 29042987 [51] \\
\hline Thyroid & siRNA & Decreased & - & 28804541 [54] \\
\hline
\end{tabular}

\subsection{YAP Inhibits Apoptosis by Interacting with TEAD Transcription Factors}

As a transcriptional co-activator, YAP does not contain a DNA-binding domain [4]. Thus, it requires binding to transcription factors of the TEAD family, TEAD1-4 [56,57], to stimulate anti-apoptotic gene expression (Figure 2). It has been demonstrated that YAP interacting with TEAD transcription factors could increase the expression of anti-apoptotic genes, such as COX-2 [15], Survivin [16,17], 
and Glut1 [18]. However, TEAD transcription factors are not the sole transcription factors, which bind to YAP. It has been reported that $\mathrm{p} 73$ is also a transcriptional partner of YAP and promotes the expression of several pro-apoptotic genes such as p53AIP1 [5], Bax [6,20], DR5 [7], and PUMA [8] (Figure 2). Thus, YAP can stimulate the expression of anti- as well as pro-apoptotic genes. This depends on the transcriptional partner of YAP (Figure 2).

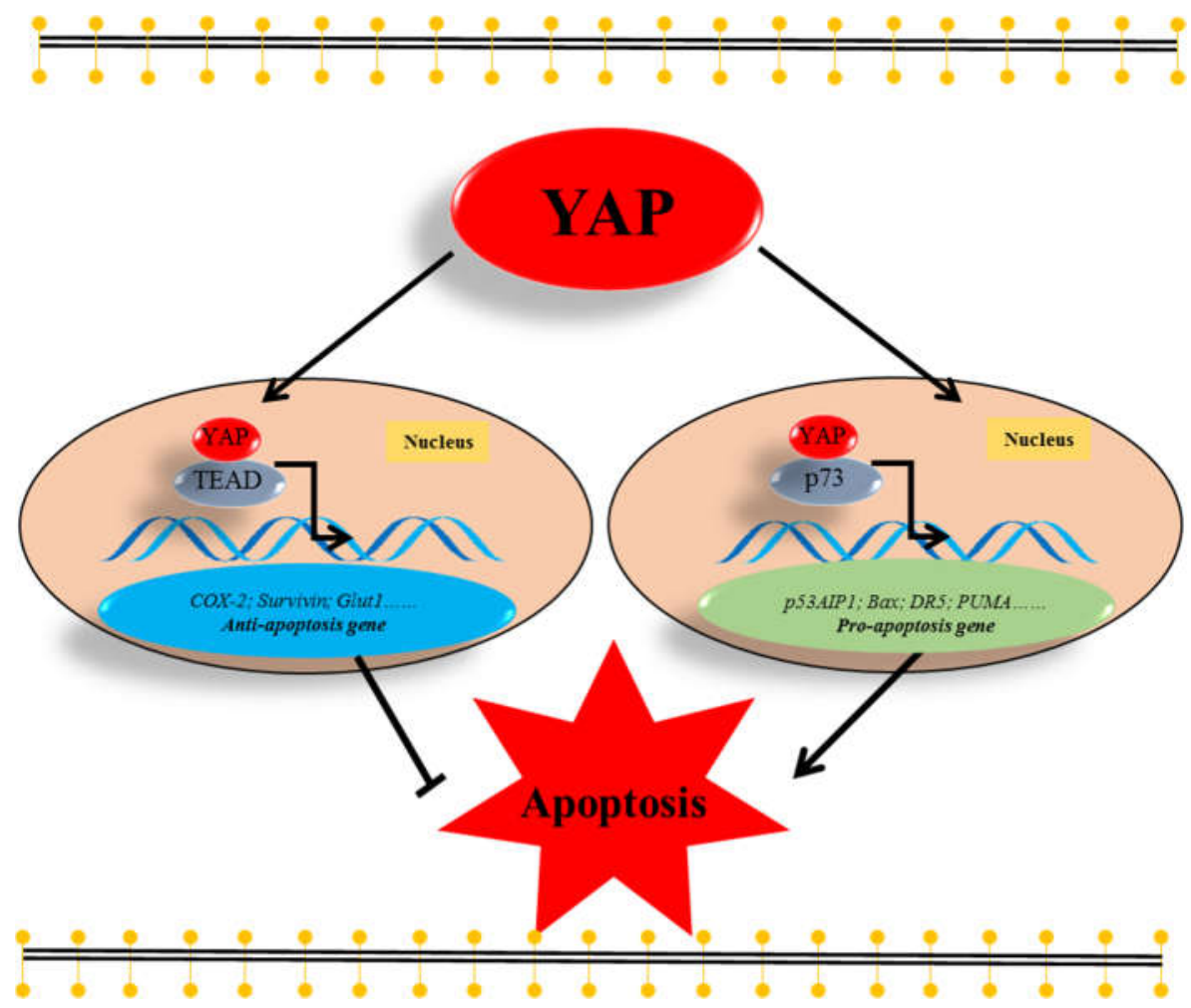

Figure 2. The bivalent role of YAP in apoptosis. In the nucleus, yes-associated protein (YAP) interacts with TEA domain (TEAD) family transcription factors and initiates the expression of anti-apoptotic genes, such as Cyclooxygenase-2 (COX-2), Survivin, and Glut1, to inhibit apoptosis. However, nuclear YAP can also interact with p73 to enhance the transcription of pro-apoptotic genes, such as p53AIP1, Bax, DR5, and PUMA to promote apoptosis. T bar: Inhibition. Arrow: Increase.

\subsection{YAP Inhibits Apoptosis by Increasing Glycolysis}

Interestingly, Wang et al. demonstrated that glucose starvation can cause YAP phosphorylation at serine 127 and inhibits YAP transcriptional activity in human embryonic kidney 293T (HEK 293T) cells and cervical cancer cells [19]. Consistent with these findings, Lin et al. observed that knockdown of YAP significantly promoted cells apoptosis, when breast cancer cells were cultured at high glucose concentration [18]. However, when the cells were cultured at low glucose concentration, the anti-apoptotic role of YAP was largely abolished [18]. In addition, Wang et al. proved that YAP promotes the expression of Glut3, which is involved in glucose metabolism [19]. These data suggest that glucose starvation is an activator of Hippo-YAP signaling pathway, and that YAP inhibits apoptosis via regulating the uptake of glucose.

\subsection{YAP Inhibits Apoptosis via Enhancing the Autophagic Flux}

It has been reported that YAP decreases cisplatin-induced apoptosis through activation of autophagy in ovarian cancer cells [58]. Moreover, Yan et al. reported that knockdown of YAP causes apoptosis via reducing mitophagy, a selective degradation of mitochondria by autophagy, in gastric cancer cells [59]. In addition, Song et al. demonstrated that YAP enhanced the autophagic flux to reduce apoptosis in nutrient deprived breast cancer cells [60]. These publications are consistent with 
the concept that YAP inhibits apoptosis via inducing autophagic flux. However, Liu et al. found that inhibition of YAP accumulation failed to have an effect on apoptosis; but can induce autophagy in thyroid papillary carcinoma cells [54]. This indicates that even though most publications support the hypothesis that YAP inhibits apoptosis by increasing the autophagic flux, the YAP-induced autophagy is not always the sole or most important factor to regulate apoptosis in cancer cells.

\section{The Pro-Apoptotic Function of YAP}

\subsection{Clinical Evidence Suggests That YAP Is a Context Specific Tumor Suppressor}

Several studies demonstrated that YAP promotes apoptosis in vitro and therefore can potentially reduce tumor growth in vivo [5-8]. This implies that YAP can have an anti-oncogenic function. Indeed, some clinical evidence supports the concept that YAP is a tumor suppressor in breast cancer and hematological cancer $[9,26]$. Yuan et al. described that $63 \%$ of infiltrating ductal breast carcinomas had lost YAP expression, but they did not demonstrate that the decreased YAP expression was associated with a poor survival in breast cancer patients [26]. Cottini et al. found that low expression of YAP was associated with short survival time in hematological cancer [9]. However, this conclusion was based only on the analysis of YAP mRNA. Interestingly, this study also showed that upregulation of YAP expression induces cell death in an ABL1 (Abelson murine leukemia viral oncogene homolog 1) activity dependent manner [9]. Thus, these publications suggest that YAP can be a tumor suppressor in a context specific manner.

\subsection{YAP Promotes Apoptosis in a p73-Dependent Manner}

It has been demonstrated that nuclear YAP interacts with p73, a tumor suppressor, to enhance apoptosis in response to DNA-damage [6,61] (Figure 2). In addition, Levy et al. reported when normal hematological cells suffer DNA damage stress, tyrosine kinase c-Abl (ABL1) enters the nucleus and phosphorylates YAP on a tyrosine residue, Y357 [62]. The Y357-phosphorylated YAP binds to p73 to promote the transcription of pro-apoptotic genes, such as p53AIPI [5], Bax [6,20], DR5 [7], and PUMA [8]. In addition, p300, which can activate p73, and promyelocytic leukemia (PML), which can increase YAP stabilization, are also involved in regulating this effect of the YAP-p73 complex [6,61]. These publications demonstrate that YAP can promote apoptosis via interaction with the transription factor p73.

\section{A Multitude of Molecules Regulate Apoptosis and Hippo-YAP Signaling}

Molecules, which inhibit or induce apoptosis and regulate Hippo-YAP signaling, were summarized in Figure 3 and Table 2. In the nucleus, YAP often interacts with TEAD transcription factors to stimulate the expression of anti-apoptotic genes $[15,18,44]$. However, it can also bind to $p 73$ and promote the expression of pro-apoptotic genes $[5-8,20]$.

\subsection{Activators of YAP, Which Impede Apoptosis}

\subsubsection{TFAP2C}

The transcription factor AP-2 Gamma (TFAP2C) is a member of the activating protein 2 (AP-2) family [63]. Some studies demonstrate that TFAP2C can increase the accumulation of cellular YAP in the nucleus by inactivating MST1/2 [42,64]. Moreover, Wang et al. reported that overexpressed TFAP2C could decrease the 5-fluorouracil-induced apoptosis in colorectal cancer cells [42]. Interestingly, they observed that this effect of TFAP2C is dependent on Rho-associated protein kinase (ROCK). This suggests that TRAFP2C inhibits apoptosis via YAP and ROCK signaling. Indeed, another publication describes that the ROCK inhibitor, Y-27632, blocked the nuclear accumulation of YAP. This demonstrates that ROCK signaling indeed regulates YAP [65]. These data imply that TFAP2C inhibits cell apoptosis via ROCK-YAP signaling and suggest an anti-apoptotic function of YAP. 


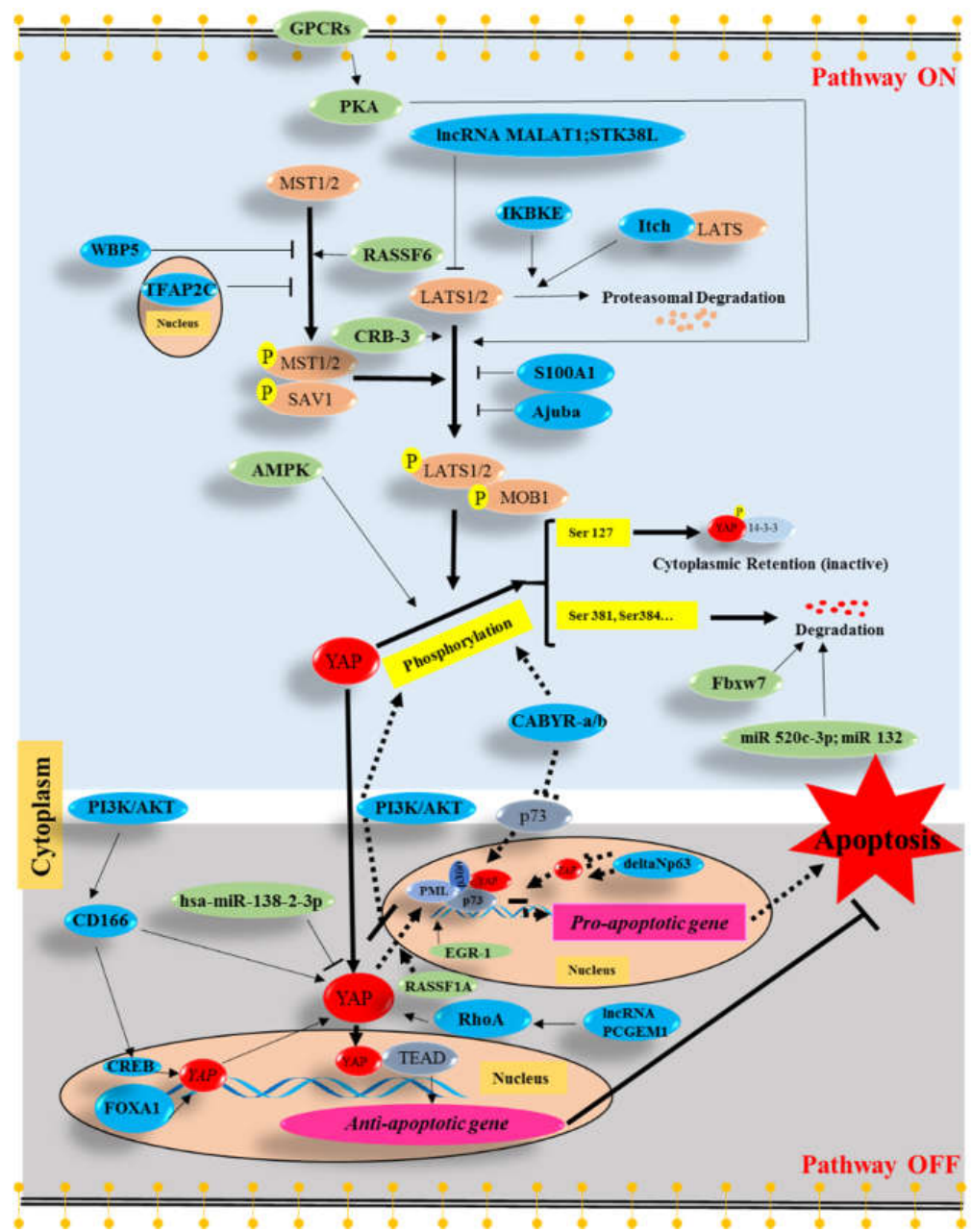

Figure 3. Many molecules regulate apoptosis and Hippo-YAP signaling pathway. Anti-apoptotic molecules are indicated in blue, whereas pro-apoptotic molecules are indicated in green. Most anti-apoptotic molecules, such as metastasis associated lung adenocarcinoma transcript 1 (MALAT1), serine/threonine kinase 38 like (STK38L), inhibitor of nuclear factor kappa B kinase subunit epsilon (IKBKE), Itch, S100 calcium-binding protein A1 (S100 A1), Ajuba, transcription factor AP-2 Gamma (TFAP2C), WW domain binding protein 5 (WBP5), lncRNA PCGEM1, Ras homolog gene family, member A (RhoA), usually allow YAP to enter the nucleus to interact with TEA domain (TEAD) family transcription factors and to activate the expression of anti-apoptotic genes. Some molecules, such as cAMP response element-binding protein (CREB) and forkhead box protein A1 (FoxA1) inhibit cell apoptosis by inducing the transcription of the $Y A P$ gene. In addition, deltaNp63 can suppress $Y A P$ gene expression to impair p73-mediated apoptosis. However, the role of deltaNp63 in YAP gene expression is still a matter of controversy. Moreover, Calcium-binding tyrosine phosphorylation-regulated protein (CABYR-a and CABYR-b, CABYR-a/b) and phosphatidylinositide 3-kinase (PI3K)/protein kinase B (AKT) signaling lead to phosphorylation of YAP at serine 127 and attenuate nuclear YAP/p73-mediated apoptosis. Additionally, PI3K/AKT signaling can also suppress apoptosis by upregulate CD166 expression. Most of the pro-apoptotic molecules, such as G-protein-coupled receptors (GPCRs), cAMP-dependent protein kinase A (PKA), Crumbs-3 (CRB-3), Ras association domain family member 6 (RASSF6), AMP-activation protein kinase (AMPK), enhance apoptosis by inducing phosphorylation of YAP and thereby impairing nuclear accumulation of YAP. In addition, some pro-apoptotic molecules, such as Fbxw7, miR520c-3p, miR132, and hsa-miR-138-2-3p enhance the degradation or block the expression of YAP. In addition, RAS association domain family 1 isoform A (RASSF1A) and early growth response-1 (EGR-1) can induce pro-apoptotic genes via the YAP-p73-p300-PML complex. T bar: Inhibition. Arrow: Increase. 


\subsubsection{WBP5}

Initially, WW domain binding protein 5 (WBP5) was described as a ligand that can bind to FBP11 WW domain [66]. Recently, it was reported that WBP5 was involved in regulating the Hippo pathway [67]. Tang et al. demonstrated that overexpressed WBP5 could inhibit the phosphorylation of MST2 and YAP without changing the level of these two proteins in lung cancer cells [68]. Moreover, immunofluorescence assays proved that upregulation of WBP5 induced the nuclear accumulation of YAP and decreased apoptosis, whereas downregulation of WBP5 lead to YAP inactive and enhanced cell apoptosis. These studies suggest an anti-apoptotic function of YAP and that WBP5 activates YAP signaling and inhibits apoptosis.

\subsubsection{IncRNA MALAT1 and STK38L}

It has been reported that downregulation of lncRNA metastasis associated lung adenocarcinoma transcript 1 (MALAT1) and serine/threonine kinase 38 like (STK38L) lead to the accumulation of LATS1 and decrease the level of cellular YAP in pancreatic cancer cells $[69,70]$. However, the mechanism, how IncRNA MALAT1 and STK38L regulate the accumulation of LATS1 and YAP, is still unknown. In addition, these studies also demonstrated that lncRNA MALAT1 and STK38L could inhibit apoptosis via unknown mechanisms $[69,70]$. These anti-apoptotic effects may be mediated by YAP and suggest an anti-apoptotic function of YAP.

\subsubsection{IKBKE and Itch}

Liu et al. demonstrated that the knockdown of nuclear factor kappa B kinase subunit epsilon (IKBKE) dramatically elevated LATS1 / 2 concentration and serine 127-phosphorylated YAP in human glioblastoma cells [71]. In contrast, it decreased the nuclear localization of YAP [71]. Moreover, inhibition of IKBKE by amlexanox suppressed the accumulation of cellular YAP and the anti-apoptotic protein, CYR61 [71,72]. These data imply that IKBKE may inhibit apoptosis by inducing the nuclear localization of YAP. This suggests a pro-oncogenic activity of YAP [71].

In addition, it was reported that Itch, a HECT class E3 ubiquitin ligase, could complex with LATS1 through the WW domains of Itch and the PPxY motifs of LATS1 [73]. Ho et al. reported that downregulation of Itch not only provoked the stabilization of LATS1, but also induced phosphorylation of YAP at serine 127 in HEK 293T cells [73]. In addition, downregulation of Itch induced cell death, while overexpressed Itch yielded the opposite effect. Thus, these data suggest that Itch can inhibit the phosphorylation of YAP and reduces apoptosis via enhancing LATS1 degradation. In addition, these data suggest an anti-apoptotic activity of YAP.

\subsubsection{S100 A1}

Recently, Guo et al. demonstrated that S100 calcium-binding protein A1 (S100 A1), which interacts with LATS1, inhibits the phosphorylation of this kinase and leads to decreased phosphorylation and increased accumulation of cellular YAP [74]. The authors also demonstrated that knockdown of S100A1 by siRNA increased cisplatin-induced apoptosis. In addition, LATS1 depletion significantly reduced the effects of S100A1 on apoptosis. Thus, this suggests that S100 A1 inhibits apoptosis and increases the accumulation of YAP. This argues for an anti-apoptotic function of YAP.

\subsubsection{Ajuba}

It was reported that Ajuba, an actin binding and scaffolding protein, can interact with LATS1/2 and thereby inhibits the activation of this kinase [75]. This leads to decreased YAP phosphorylation [75]. Interestingly, Ajuba does not only decrease the phosphorylation of YAP, but also inhibits apoptosis of cervical cancer cells [76]. This suggests that inhibition of apoptosis by Ajuba correlates with decreased YAP phosphorylation and implies an anti-apoptotic function of YAP. However, we do not fully understand if and how YAP signaling is important for the inhibition of apoptosis by Ajuba. 


\subsubsection{IncRNA PCGEM1 and RhoA}

Prostate cancer gene expression marker 1 (PCGEM1) is an lncRNA that is initially found to be overexpressed in aggressive prostate cancers [77]. Recently, Chen et al. reported that overexpressed lncRNA PCGEM1 could decrease apoptosis in ovarian cancer cells [78]. Subsequently, they found that upregulated lncRNA PCGEM1 increased the expression of RhoA, which can enhance activity and accumulation of cellular YAP [79]. In addition, the authors also reported that downregulated PCGEM1 could promote apoptosis via decreasing RhoA expression. However, silencing the expression of RhoA reversed the anti-apoptotic effect of PCGEM1 and significantly inhibited the total level of YAP protein [78]. This suggests that PCGEM1 inhibits apoptosis and induces the accumulation of YAP via RhoA. Thus, YAP might have an anti-apoptotic function in this context.

\subsubsection{CREB and FOXA1}

Cyclic adenosine monophosphate (cAMP) response element-binding (CREB) protein is a ubiquitous transcription factor that activates the transcriptional activity of various promoters [80]. Wang et al. reported that CREB could promote YAP transcription through binding to a novel region (608/439 base pairs) within the YAP promoter in liver cancer cells [81]. In addition, the same research group also found that CD166 could inhibit apoptosis via increasing the accumulation of CREB and cellular YAP [49]. These studies suggest that YAP might be anti-apoptotic.

Some studies demonstrated that forkhead box protein A1 (FOXA1), a member of forkhead box gene superfamily, inhibits apoptosis in cancer cells $[82,83]$. Consistent with these in vitro data, Ren et al. observed that gastric cancer patients with high expression of FOXA1 had poorer five-year overall survival [84]. Moreover, Ma et al. reported that FOXA1 could be detected in 57.8\% (52/90) of the colorectal cancer specimens, whereas only in 37.8\% (34/90) of the non-cancerous specimens [85]. Moreover, the patients with FOXA1 expression had poor survival. It was also demonstrated that FOXA1 knockdown evidently induced apoptosis; while it decreased the expression of YAP [85]. Interestingly, Yu et al. reported that in liver cancer cells FOXA1 was able to bind the R2 region of the YAP promoter, which contains a CREB binding motif [86]. Additionally, FOXA1 overexpression recruited CREB onto the $\mathrm{R} 2$ region. These data suggest that FOXA1 facilitates $Y A P$ transcription via enhancing the binding of CREB to the YAP promoter. These studies demonstrate that FOXA1 inhibits apoptosis and increases the expression of $Y A P$, which suggests an anti-apoptotic function of YAP.

\subsection{Activators of YAP, Which Induce Apoptosis}

\subsubsection{RASSF1A}

Numerous studies have argued that RASSF1A (Ras association domain family 1 isoform A) is a tumor suppressor $[8,87,88]$. Matallanas et al. found that RASSF1A allows YAP to move to the nucleus and to interact with p73 [8]. The YAP-p73 complex results in transcription of the pro-apoptotic target gene PUMA in breast cancer cells [8] and Ankyrin Repeat Domain 1 (ANKRD1), which is in some circumstances considered to be a tumor suppressor gene, because it is epigenetically inactivated in human cancer and reduces colony formation of cancer cells [87]. In addition, Yee et al. found that a RASSF1A polymorphism, RASSF1A-p.133Ser, failed to enhance YAP-p73 mediated apoptosis [88]. Furthermore, they demonstrated that male soft tissue sarcoma patients, who carried the RASSF1A-p.133Ser allele, exhibited poorer tumor-specific survival [88]. This suggests that the tumor suppressor function of RASSF1A may be due to YAP-p73 mediated apoptosis. However, Donninger et al. reported that the anti-tumor function of RASSF1 is rather caused by inhibition of proliferation than its pro-apoptotic effect [89]. Nevertheless, all these publications suggest that RASSF1A induces apoptosis and that YAP can have a pro-apoptotic function, when interacting with p73. 


\subsubsection{EGR-1}

Early growth response-1 (EGR-1) is a nuclear protein and functions as a transcriptional regulator [90]. Zagurovskaya et al. demonstrated that EGR-1 interacts with YAP through its PPxY motif and that this interaction is required for inducing clonogenic cell death in prostate carcinoma cells [91]. In addition, several studies reported that EGR-1 served as a tumor suppressor in colorectal carcinoma [92-94], gliomas [92-94], and colon carcinoma [92-94]. However, the role of EGR-1 in cancer is still a matter of controversy [95]. For example, Virolle et al. proved that EGR1 promotes the progression of prostate cancer [96]. These studies suggest that EGR-1 induces cell death and YAP might have a pro-apoptotic function when interacting with EGR-1.

\subsection{Inhibitors of YAP, Which Induce Apoptosis}

\subsubsection{GPCRs and PKA}

G-protein-coupled receptors (GPCRs), the largest family of cell surface receptors, have been considered to be upstream regulators of the Hippo pathway $[14,97,98]$. Yu et al. reported that lysophosphatidic acid (LPA) and sphingosine 1-phosphophate (S1-P) inhibit LATS1/2 activity via blocking G12- and G13-coupled receptors, which activate YAP function and promote cell migration and proliferation [14]. In contrast, GPCRs activators, such as glucagon and epinephrine could activate LATS1/2 and inhibit YAP function [14]. Kim et al. observed that the GPRCs-triggered LATS2-YAP pathway depends on cAMP-dependent protein kinase A (PKA) [97]. In addition, they demonstrated that PKA could phosphorylate LATS2, and thereby enhances LATS2 activity sufficiently to phosphorylate YAP at serine 381 [97], which leads to the degradation of YAP [99]. Moreover, Zhang et al. also observed that GPCRs and PKA could induce YAP phosphorylation via promoting LATS1 phosphorylation [98]. Consistent with these findings, the authors reported that induction of apoptosis by omega-3 polyunsaturated fatty acid is mediated by GPCRs [98]. These data suggest that GPCR/PKA signaling induces apoptosis and inhibits YAP function, suggesting an anti-apoptotic function of YAP.

\subsubsection{RASSF6}

He et al. found that Ras association domain family member 6 (RASSF6) overexpression could increase cisplatin-induced apoptosis, while depletion of RASSF6 had the opposite effect in breast cancer cells [100]. The authors observed that RASSF6 decreased cellular YAP concentration and activated the Hippo signaling pathway by upregulating the phosphorylation of MST1/2 and LATS1. In addition, overexpression of YAP inhibited the RASSF6 and cisplatin-induced apoptosis. Thus, these data suggest that RASSF6 induces apoptosis through activation of the Hippo pathway leading to the inhibition of YAP function. These data suggest an anti-apoptotic function of YAP.

\subsubsection{CRB-3}

Recently, it was reported that crumbs-3 (CRB-3), the major crumbs isoform in mammalian epithelial cells [101], is involved in Hippo signaling. Mao et al. found that overexpressed CRB-3 could induce the serine 127-phosphorylated YAP, and decreased the accumulation of nuclear YAP protein in mammary epithelial cells [102]. In addition, they also reported in a xenograft study that CRB-3 increased cell death within tumors. Moreover, Szymaniak et al. demonstrated that CRB-3 promoted the interaction between YAP and LATS1/2 in lung epithelial cells [103]. This led to increased phosphorylation and cytoplasmic sequestration of YAP [103]. Thus, CRB-3 blocks YAP function and induces cell death, implying a pro-oncogenic function of YAP. 


\subsubsection{AMPK}

Mo et al. reported that the activation of AMP-activation protein kinase (AMPK) inhibits the activity of YAP [104]. They demonstrated that metformin or aminoimidazole carboxamide ribonucleotide (AICAR), two well-known AMPK activators, increased the serine 127-phosphorylated YAP in primary mouse hepatocytes. Moreover, these two substances decreased the expression of anti-apoptotic genes, such as CTGF and CYR61 [72,105]. Consistent with this study, Wang et al. also found that an AMPK $\alpha 1$ C-terminal-truncated mutant (amino acids 1-312), which has been demonstrated to be a constitutively active form of AMPK, induced the phosphorylation of YAP in HEK 293T cells [19]. In addition, Jiang et al. proved that resveratrol, a natural polyphenol present in most plants, inhibited YAP accumulation in pancreatic cancer cells [40]. However, knockdown of AMPK rescued the resveratrol-induced suppression of YAP [40]. This suggests that AMPK induces apoptosis and impairs the function of YAP via enhancing YAP phosphorylation. This could lead in vivo to larger tumors, suggesting a pro-oncogenic function of YAP.

\subsubsection{Fbxw7, miR520c-3p, miR132, and hsa-miR-138-2-3p}

It was suggested that F-box and WD repeat domain-containing 7 (Fbxw7), a well-known F-box protein in the SCF (SKP1-CUL1-F-box protein) E3 ligase complex [106], can directly bind to YAP and decreases the accumulation of YAP in hepatocellular carcinoma cells [107]. In addition, the proteasome inhibitor MG132 was able to prevent the downregulation of YAP in Fbxw7 overexpressing cells, suggesting that Fbxw7 targets YAP for degradation by proteasomes [107]. Tu et al. reported that Fbxw7 expression could induce cell apoptosis and that restoring YAP expression lead to a significant reduction of apoptosis [107]. Thus, these data suggest that Fbxw7 induces apoptosis by inducing the degradation of YAP. Since loss of Fbxw7 expression was associated with poor clinicopathological features including large tumor size [107], YAP might have a pro-oncogenic function in this context.

Some molecules, such as miR520c-3p [108] or miR132 [108], have been reported to enhance the degradation of YAP and induce apoptosis of hepatocellular carcinoma cells by an unknown mechanisms. In addition, Zhu et al. reported that hsa-miR-138-2-3p prevented the accumulation of cellular YAP and induced apoptosis in human laryngeal cancer stem cells [109]. These publications also argue for an anti-apoptotic function of YAP.

\subsection{Inhibitors of YAP Which Impede Apoptosis}

\subsubsection{DeltaNp63}

DeltaNp63 is an isoform of p63, which lacks the acidic transactivation (TA) domain and antagonizes p53, TAp63 and TAp73 by inhibiting the expression of their downstream target genes [110]. Interestingly, Ehsanian et al. observed that deltaNp63 binds to the promotor of $Y A P$ and suppresses $Y A P$ expression in head and neck cancer cells [111]. Surprisingly, Li et al. also observed that deltaNp63 directly binds to the YAP promoter, but claimed that this induces YAP gene expression in squamous cell carcinoma cell lines [112]. Possibly, the effect of deltaNp63 on gene expression of target genes depends on many additional transcription factors, which might be differently expressed in distinct cell lines. In addition, Ehsanian et al. could also clearly demonstrate that deltaNp63 and the knock down of YAP inhibits apoptosis [111]. This suggests that YAP has a pro-apoptotic effect in head and neck cancer cells.

\subsubsection{CABYR}

Calcium-binding tyrosine phosphorylation-regulated (CABYR) protein is isolated from human spermatozoa and participates in the sperm capacitation [113]. Recently, Xiao et al. described that, in lung cancer cells, silencing of the CABYR- $a$ and $C A B Y R-b$ genes $(C A B Y R-a / b)$ inhibits the phosphorylation of YAP at serine 127, which usually leads to increased nuclear localization of YAP [7]. This study also demonstrated that silencing of $C A B Y R-a / b$ increased the percentage of dead cells and 
that this induction of apoptosis could be inhibited by knocking down of YAP and p73 [7]. Moreover, overexpression of YAP plus p73, but not the expression of either protein alone, effectively promoted cell apoptosis, suggesting that both proteins must be present to induce apoptosis. These data suggest that depletion of CABYR-a/b sensitizes lung cancer cells to apoptosis in a YAP/p73 dependent manner [7]. This implies that YAP, when interacting with $\mathrm{p} 73$, has a pro-apoptotic effect in lung cancer cells.

\subsubsection{PI3K/AKT}

Current evidence demonstrates that activated phosphatidylinositide 3-kinase (PI3K)/protein kinase B (AKT) signaling can phosphorylate YAP at serine 127 [114] (Table 2). The serine 127-phosphorylated YAP interacts with 14-3-3 and is sequestered in the cytoplasm, which attenuates nuclear YAP/p73-mediated apoptosis [114]. Consistent with this publication, Ehsanian et al. could also demonstrate that AKT can inhibit apoptosis via phosphorylating YAP at serine 127 [111]. In addition, PI3K/AKT signaling can also upregulate CD166 expression [49]. Subsequently, CD166 enhances YAP expression and activity to suppress apoptosis in liver cancer cells [49]. These data suggest that PI3K/AKT signaling inhibits apoptosis by regulating YAP activity via at least two different mechanisms.

Table 2. Molecules regulate Hippo-YAP signaling and apoptosis.

\begin{tabular}{|c|c|c|c|c|}
\hline Molecule & Target & YAP & Apoptosis & PMID \\
\hline \multicolumn{5}{|c|}{ a. Activators of YAP, which impede apoptosis } \\
\hline TFAP2C & MST1/2 & Increases nuclear YAP & Decreased & 29439714 [42] \\
\hline WBP5 & MST2 & Increases nuclear YAP & Decreased & $27336605[68]$ \\
\hline lncRNA MALAT1 & LATS1 & Increases cellular YAP & Decreased & $29215734[69]$ \\
\hline STK38L & LATS2 & Increases cellular YAP & Decreased & $29108249[70]$ \\
\hline IKBKE & LATS1/2 & Decreases phosphorylation of YAP & Decreased & $29048430[71]$ \\
\hline Itch & LATS1 & Decreases phosphorylation of YAP & Decreased & $21383157[73]$ \\
\hline S100 A1 & LATS1 & Decreases phosphorylation of YAP & Decreased & 29901195 [74] \\
\hline Ajuba & LATS1/2 & Decreases phosphorylation of YAP & Decreased & 20303269 [75] \\
\hline lncRNA PCGEM1 & RhoA & Increases cellular YAP & Decreased & $29949791[78]$ \\
\hline CREB & YAP & Increases $Y A P$ gene transcription & Decreased & 24482231 [49] \\
\hline \multicolumn{5}{|c|}{ b. Activators of YAP, which induce apoptosis } \\
\hline RASSF1A & YAP & Increases nuclear YAP & Increased & $17889669[8]$ \\
\hline EGR-1 & YAP & Forms a complex with YAP & Increased & 19137013 [91] \\
\hline \multicolumn{5}{|c|}{ c. Inhibitors of YAP, which induce apoptosis } \\
\hline GPCRs & PKA & Phosphorylates YAP at serine 381 & Increased & 23644383 [97] \\
\hline RASSF6 & MST1/2 & Decreases cellular YAP & Increased & 29964010 [100] \\
\hline CRB-3 & LATS1/2 & Increases phosphorylation of YAP & Increased & 28079891 [102] \\
\hline AMPK & YAP & Increases phosphorylation of YAP & Increased & $25751140[104]$ \\
\hline Fbxw7 & YAP & Increases YAP degradation & Increased & 24884509 [107] \\
\hline miR520c-3p & YAP & Decreases $Y A P$ gene expression & Increased & 27633306 [108] \\
\hline $\operatorname{miR} 132$ & YAP & Decreases YAP gene expression & Increased & $27633306[108]$ \\
\hline Hsa-miR-138-2-3p & YAP & Decreases cellular YAP & Increased & 28533948 [109] \\
\hline \multicolumn{5}{|c|}{ d. Inhibitors of YAP, which impede apoptosis } \\
\hline deltaNp63 & YAP & Controversy in $Y A P$ gene expression & Decreased & 28923839 [111] \\
\hline CABYR & YAP & Increases phosphorylation of YAP & Decreased & $26843620[7]$ \\
\hline PI3K/AKT & YAP & Increases phosphorylation of YAP & Decreased & 12535517 [114] \\
\hline
\end{tabular}

Phosphorylates YAP at serine 127.

\section{Compounds, Regulating Hippo-YAP Signaling, Induce Apoptosis, and Impair Cancer}

Some studies demonstrate that Hippo-YAP signaling might be a promising target for therapies to impair cancer [115]. Since YAP is the most important functional component of the Hippo-YAP signaling pathway, it may be a more promising therapeutic target than other proteins.

Several compounds have been proven to regulate apoptosis via, or partly via, regulating Hippo-YAP signaling (Table 3). These compounds can be classified into five categories: (a) compounds 
that regulate upstream molecules of YAP or YAP per se to inhibit YAP accumulation, such as omega-3 polyunsaturated fatty acids ( $\omega-3$ PUFAs) [98], gossypol [116], resveratrol [40], 17-DMAG [117], amlexanox [71] and tubacin [117], norcantharidin [118,119], JQ1 [120], oligomeric proanthocyanidins (OPCs) [121]; (b) compounds that promote the phosphorylation of YAP and block YAP nuclear translocation, such as dobutamine [122], huaier [123], GCCSysm-4 (G4) [15], scutellarin [124] and hydrogen sulfide-releasing oleanolic acid (HS-OA) [125]; (c) compounds that inhibit the interaction of YAP and TEAD transcription factors, such as verteporfin [126-128] and CA3 [129], or inhibit the interaction of YAP and p63, such as nicotine [130]; (d) compounds that increase YAP accumulation, such as IBS003031 [131] and actinomycin D [132]; (e) compounds that regulate the YAP-p73 complex, such as $\alpha$-TEA [133]. Many of these mentioned compounds are currently used in clinical trials (Table 3 ). This increases the expectation that targeting the Hippo-YAP signaling pathway will become an efficient way to treat cancer.

Table 3. Compounds regulating Hippo-YAP signaling, tumor progression, and apoptosis.

\begin{tabular}{|c|c|c|c|c|c|c|}
\hline Compounds & Cancer & Target & TW/TV* & Apoptosis & Clinical Trials $^{\dagger}$ & PMID \\
\hline \multicolumn{7}{|c|}{ Regulate upstream molecules of YAP or YAP per se to decrease YAP expression } \\
\hline$\omega-3$ PUFAs & $\mathrm{CR}$ & GPCRs & $?$ & I & $>20$ & $27506947[98]$ \\
\hline Gossypol & Ovarian & LATS1 & $?$ & I & 10 & 25180175 [116] \\
\hline Resveratrol & Pancreas & AMPK & $?$ & I & 9 & $27669292[40]$ \\
\hline 17-DMAG & Breast & HSP90 & $\mathrm{D}$ & I & 4 & 28529458 [117] \\
\hline Amlexanox & Glioblastoma & IKBKE & $\mathrm{D}$ & $\mathrm{I}$ & 1 & 29048430 [71] \\
\hline Tubacin & Breast & HDAC6 & $\mathrm{D}$ & I & 0 & 28529458 [117] \\
\hline Norcantharidin & Lung & YAP & $?$ & I & 0 & $\begin{array}{l}29901163 \text { [118] } \\
27903989 \text { [119] }\end{array}$ \\
\hline JQ1 & Chondrosarcoma & YAP & $?$ & I & 0 & 28059436 [120] \\
\hline OPCs & CR & YAP & $\mathrm{D}$ & I & 0 & 29463813 [121] \\
\hline \multicolumn{7}{|c|}{ Promote the phosphorylation of YAP and block YAP nuclear translocation } \\
\hline Dobutamine & Stomach & YAP & $?$ & I & $>20$ & $25493021[122]$ \\
\hline Huaier & Liver & YAP & $?$ & I & 6 & 29187885 [123] \\
\hline G4 & $\mathrm{CR}$ & YAP & $\mathrm{D}$ & I & 0 & $29037225[15]$ \\
\hline Scutellarin & Breast & YAP & $\mathrm{D}$ & I & 0 & 29079722 [124] \\
\hline HS-OA & Liver & YAP-14-3-3 & $\mathrm{D}$ & I & 0 & 27437776 [125] \\
\hline \multicolumn{7}{|c|}{ Inhibit the interaction of YAP and TEAD or the interaction of YAP and p63 } \\
\hline & Pancreas & & $\mathrm{D}$ & I & & 28002618 [126] \\
\hline Verteporfin & UM & YAP-TEAD & $?$ & I & 9 & 28042502 [127] \\
\hline & $\mathrm{CR}$ & & $?$ & I & & $27383277[128]$ \\
\hline CA3 & Esophagus & YAP-TEAD & $\mathrm{D}$ & I & 0 & 29167315 [129] \\
\hline Nicotine & Esophagus & YAP-p63 & $?$ & $\mathrm{D}$ & $>20$ & 24621512 [130] \\
\hline \multicolumn{7}{|c|}{ Increase YAP Expression } \\
\hline IBS003031 & $\mathrm{MM}$ & YAP & $?$ & I & 0 & 29061667 [131] \\
\hline $\begin{array}{c}\text { Actinomycin } \\
\text { D }\end{array}$ & Liver & YAP & $\mathrm{D}$ & I & $>20$ & 27836738 [132] \\
\hline \multicolumn{7}{|c|}{ Regulate the YAP-p73 complex } \\
\hline$\alpha$-TEA & Breast & YAP-p73 & $?$ & I & 1 & 21214929 [133] \\
\hline
\end{tabular}

* TW: Tumor weight; TV: Tumor volume; D: Decreased; + search in https:/ clinicaltrials.gov/; we excluded clinical trial with status of not yet recruiting, suspended, terminated, withdrawn and unknown. $\omega-3$ PUFAs: Omega-3 polyunsaturated fatty acids; CR: Colon/Rectum; GPCRs: G-protein-coupled receptors; LATS1: Large tumor suppressor kinases1; AMPK: AMP-activation protein kinase; HSP90: Heat shock protein 9; IKBKE: Inhibitor of nuclear factor kappa B kinase subunit epsilon; HDAC6: Histone deacetylase 6; OPCs: Oligomeric proanthocyanidins; G4: GCCSysm-4; HS-OA: Hydrogen sulfide-releasing oleanolic acid; UM: Uveal melanoma; MM: Multiple myeloma.

?: Studies did not measure tumor weight or tumor volume. 


\section{Conclusions and Future Perspectives}

In conclusion, current evidence suggests that YAP, the core component of Hippo-YAP signaling pathway, has an ambivalent role in cell apoptosis. It can bind to TEAD transcription factors to promote the transcription of anti-apoptotic genes, such as COX-2 [15], Survivin [16,17], and Glut1 [18]. However, it can also initiate the transcription of pro-apoptotic genes, such as p53AIP1 [5], Bax [6,20], DR5 [7], and PUMA [8]. In addition, the clinical data also demonstrate that YAP can function as an oncogene in several cancers [21,22,27], while it can also serve as a tumor suppressor in breast cancer [60] and hematological cancer [9]. This suggests YAP has ambivalent functions. It can promote or inhibit tumor progression dependent on other signaling pathways and the cancer type. These data also imply that a therapy, which targets the Hippo-YAP signaling pathway, might be of benefit to only a subset of patients.

Thus, there are several questions that should be addressed before targeting Hippo-YAP signaling pathway to treat cancer patients: One main question is, if YAP inhibitors in combination with traditional drugs, such as gemcitabine and cisplatin, induce cell death and impair cancer growth. Several promising studies have already demonstrated that YAP inhibitors can restore sensitivity to gemcitabine and cisplatin in several cancers $[40,134,135]$. On the contrary, Gujral et al. described that nuclear YAP enhances gemcitabine effectiveness by downregulating multidrug transporters [136]. In addition, previous studies also found that YAP enhances p73 mediated apoptosis when DNA damage stress is induced by cisplatin $[5,6,62]$. These contradictory studies suggest that YAP inhibitors might not always inhibit tumor growth, but might also foster tumor growth. Other important questions are: (a) Is nuclear YAP abnormally expressed in individual cancer types and is its expression associated with poor survival or good survival of cancer patients? This is crucial for deciding, if a YAP inhibitor or a YAP activator should be applied. (b) How do distinct drugs, which regulate Hippo-YAP signaling, compare in their efficacy to each other? (c) Are some drugs especially useful, because they do not only regulate YAP, but also modify other signaling pathways? These questions need to be addressed in order to provide a solid basis for planning clinical trials.

\section{Note}

This review was performed according to the PRISMA guidelines. Publications were identified by searching PubMed, on 5 July 2018, using the following search strategy: (Hippo [tiab] OR YAP [tiab]) AND (apoptosis [tiab] OR autophagy [tiab]) AND (neoplasms [tiab] OR cancer [tiab]). Inclusion criteria: We included all studies which investigated the "mechanism of interaction between YAP and autophagy" or the "mechanisms of interaction between YAP and apoptosis". Exclusion criteria: We excluded article types, which were reviews or commentaries; literature written not in English and irrelevant literature (literature which does not meet the inclusion criteria). We also added publications, which were cited in the reference list of the included literature or suggested by reviewers. In addition, we searched the ClinicalTrials.gov data base, in order to find clinical trials using drugs, which are involved in regulating the Hippo-YAP signaling pathway.

Author Contributions: Conceptualization, X.Z., B.V., and D.Z.; Methodology, X.Z. and D.Z.; Literature Review, X.Z. and A.A.; Writing-Original Draft Preparation, X.Z., D.Z., and B.V.; Writing-Review \& Editing, X.Z., A.A., B.V., and D.Z.; Supervision, B.V. and D.Z.; Funding Acquisition, X.Z., B.V., and D.Z.

Funding: Xianbin Zhang was supported by the China Scholarship Council (grant number: 201608080159). The study was supported by the Deutsche Forschungsgemeinschaft (DFG research group for 2591, grant number: 321137804, ZE 712/1-1 and VO312 450/15-1).

Conflicts of Interest: The authors declare no conflict of interest. 


\section{References}

1. Moroishi, T.; Hansen, C.G.; Guan, K.L. The emerging roles of YAP and TAZ in cancer. Nat. Rev. Cancer 2015, 15, 73-79. [CrossRef] [PubMed]

2. Hilman, D.; Gat, U. The evolutionary history of YAP and the hippo/YAP pathway. Mol. Biol. Evol. 2011, 28, 2403-2417. [CrossRef] [PubMed]

3. Zhou, W.; Zhao, M. How Hippo Signaling Pathway Modulates Cardiovascular Development and Diseases. J. Immunol. Res. 2018, 2018, 3696914. [CrossRef] [PubMed]

4. Johnson, R.; Halder, G. The two faces of Hippo: Targeting the Hippo pathway for regenerative medicine and cancer treatment. Nat. Rev. Drug Discov. 2014, 13, 63-79. [CrossRef] [PubMed]

5. Lapi, E.; Di Agostino, S.; Donzelli, S.; Gal, H.; Domany, E.; Rechavi, G.; Pandolfi, P.P.; Givol, D.; Strano, S.; $\mathrm{Lu}, \mathrm{X}$.; et al. PML, YAP, and p73 are components of a proapoptotic autoregulatory feedback loop. Mol. Cell 2008, 32, 803-814. [CrossRef] [PubMed]

6. Strano, S.; Monti, O.; Pediconi, N.; Baccarini, A.; Fontemaggi, G.; Lapi, E.; Mantovani, F.; Damalas, A.; Citro, G.; Sacchi, A.; et al. The transcriptional coactivator Yes-associated protein drives p73 gene-target specificity in response to DNA Damage. Mol. Cell 2005, 18, 447-459. [CrossRef] [PubMed]

7. Xiao, Q.; Qian, Z.; Zhang, W.; Liu, J.; Hu, E.; Zhang, J.; Li, M.; Wang, J.; Kong, F.; Li, Y.; et al. Depletion of CABYR-a/b sensitizes lung cancer cells to TRAIL-induced apoptosis through YAP/p73-mediated DR5 upregulation. Oncotarget 2016, 7, 9513-9524. [CrossRef] [PubMed]

8. Matallanas, D.; Romano, D.; Yee, K.; Meissl, K.; Kucerova, L.; Piazzolla, D.; Baccarini, M.; Vass, J.K.; Kolch, W.; O'Neill, E. RASSF1A elicits apoptosis through an MST2 pathway directing proapoptotic transcription by the p73 tumor suppressor protein. Mol. Cell 2007, 27, 962-975. [CrossRef] [PubMed]

9. Cottini, F.; Hideshima, T.; Xu, C.; Sattler, M.; Dori, M.; Agnelli, L.; ten Hacken, E.; Bertilaccio, M.T.; Antonini, E.; Neri, A.; et al. Rescue of Hippo coactivator YAP1 triggers DNA damage-induced apoptosis in hematological cancers. Nat. Med. 2014, 20, 599-606. [CrossRef] [PubMed]

10. Bertini, E.; Oka, T.; Sudol, M.; Strano, S.; Blandino, G. YAP: At the crossroad between transformation and tumor suppression. Cell. Cycle 2009, 8, 49-57. [CrossRef] [PubMed]

11. Cottini, F.; Anderson, K.C.; Tonon, G. Awakening the Hippo co-activator YAP1, a mercurial cancer gene, in hematologic cancers. Mol. Cell. Oncol. 2014, 1, e970055. [CrossRef] [PubMed]

12. Yagi, R.; Chen, L.F.; Shigesada, K.; Murakami, Y.; Ito, Y. A WW domain-containing yes-associated protein (YAP) is a novel transcriptional co-activator. EMBO J. 1999, 18, 2551-2562. [CrossRef] [PubMed]

13. Zhao, B.; Wei, X.; Li, W.; Udan, R.S.; Yang, Q.; Kim, J.; Xie, J.; Ikenoue, T.; Yu, J.; Li, L.; et al. Inactivation of YAP oncoprotein by the Hippo pathway is involved in cell contact inhibition and tissue growth control. Genes Dev. 2007, 21, 2747-2761. [CrossRef] [PubMed]

14. Yu, F.X.; Zhao, B.; Panupinthu, N.; Jewell, J.L.; Lian, I.; Wang, L.H.; Zhao, J.; Yuan, H.; Tumaneng, K.; Li, H.; et al. Regulation of the Hippo-YAP pathway by G-protein-coupled receptor signaling. Cell 2012, 150, 780-791. [CrossRef] [PubMed]

15. Li, W.; Cao, Y.; Xu, J.; Wang, Y.; Li, W.; Wang, Q.; Hu, Z.; Hao, Y.; Hu, L.; Sun, Y.; et al. YAP transcriptionally regulates COX-2 expression and GCCSysm-4 (G-4), a dual YAP/COX-2 inhibitor, overcomes drug resistance in colorectal cancer. J. Exp. Clin. Cancer Res. 2017, 36, 144. [CrossRef] [PubMed]

16. Dong, J.; Feldmann, G.; Huang, J.; Wu, S.; Zhang, N.; Comerford, S.A.; Gayyed, M.F.; Anders, R.A.; Maitra, A.; Pan, D. Elucidation of a universal size-control mechanism in Drosophila and mammals. Cell 2007, 130, 1120-1133. [CrossRef] [PubMed]

17. Zhang, W.; Gao, Y.; Li, F.; Tong, X.; Ren, Y.; Han, X.; Yao, S.; Long, F.; Yang, Z.; Fan, H.; et al. YAP promotes malignant progression of Lkb1-deficient lung adenocarcinoma through downstream regulation of survivin. Cancer Res. 2015, 75, 4450-4457. [CrossRef] [PubMed]

18. Lin, C.; Xu, X. YAP1-TEAD1-Glut1 axis dictates the oncogenic phenotypes of breast cancer cells by modulating glycolysis. Biomed. Pharmacother. 2017, 95, 789-794. [CrossRef] [PubMed]

19. Wang, W.; Xiao, Z.D.; Li, X.; Aziz, K.E.; Gan, B.; Johnson, R.L.; Chen, J. AMPK modulates Hippo pathway activity to regulate energy homeostasis. Nat. Cell. Biol. 2015, 17, 490-499. [CrossRef] [PubMed]

20. Howell, M.; Borchers, C.; Milgram, S.L. Heterogeneous nuclear ribonuclear protein U associates with YAP and regulates its co-activation of Bax transcription. J. Biol. Chem. 2004, 279, 26300-26306. [CrossRef] [PubMed] 
21. Salcedo Allende, M.T.; Zeron-Medina, J.; Hernandez, J.; Macarulla, T.; Balsells, J.; Merino, X.; Allende, H.; Tabernero, J.; Ramon, Y.C.S. Overexpression of Yes Associated Protein 1, an Independent Prognostic Marker in Patients with Pancreatic Ductal Adenocarcinoma, Correlated with Liver Metastasis and Poor Prognosis. Pancreas 2017, 46, 913-920. [CrossRef] [PubMed]

22. Rozengurt, E.; Sinnett-Smith, J.; Eibl, G. Yes-associated protein (YAP) in pancreatic cancer: At the epicenter of a targetable signaling network associated with patient survival. Signal Transduct. Target. Ther. 2018, 3, 11. [CrossRef] [PubMed]

23. Wang, T.; Mao, B.; Cheng, C.; Zou, Z.; Gao, J.; Yang, Y.; Lei, T.; Qi, X.; Yuan, Z.; Xu, W.; et al. YAP promotes breast cancer metastasis by repressing growth differentiation factor-15. Biochim. Biophys. Acta Mol. Basis Dis. 2018, 1864, 1744-1753. [CrossRef] [PubMed]

24. Di Agostino, S.; Sorrentino, G.; Ingallina, E.; Valenti, F.; Ferraiuolo, M.; Bicciato, S.; Piazza, S.; Strano, S.; Del Sal, G.; Blandino, G. YAP enhances the pro-proliferative transcriptional activity of mutant p53 proteins. EMBO Rep. 2016, 17, 188-201. [CrossRef] [PubMed]

25. Sorrentino, G.; Ruggeri, N.; Zannini, A.; Ingallina, E.; Bertolio, R.; Marotta, C.; Neri, C.; Cappuzzello, E.; Forcato, M.; Rosato, A.; et al. Glucocorticoid receptor signalling activates YAP in breast cancer. Nat. Commun. 2017, 8, 14073. [CrossRef] [PubMed]

26. Yuan, M.; Tomlinson, V.; Lara, R.; Holliday, D.; Chelala, C.; Harada, T.; Gangeswaran, R.; Manson-Bishop, C.; Smith, P.; Danovi, S.A.; et al. Yes-associated protein (YAP) functions as a tumor suppressor in breast. Cell. Death Differ. 2008, 15, 1752-1759. [CrossRef] [PubMed]

27. Maugeri-Sacca, M.; De Maria, R. The Hippo pathway in normal development and cancer. Pharmacol. Ther. 2018, 186, 60-72. [CrossRef] [PubMed]

28. Lau, A.N.; Curtis, S.J.; Fillmore, C.M.; Rowbotham, S.P.; Mohseni, M.; Wagner, D.E.; Beede, A.M.; Montoro, D.T.; Sinkevicius, K.W.; Walton, Z.E.; et al. Tumor-propagating cells and Yap/Taz activity contribute to lung tumor progression and metastasis. EMBO J. 2014, 33, 468-481. [CrossRef] [PubMed]

29. Touil, Y.; Igoudjil, W.; Corvaisier, M.; Dessein, A.F.; Vandomme, J.; Monte, D.; Stechly, L.; Skrypek, N.; Langlois, C.; Grard, G.; et al. Colon cancer cells escape 5FU chemotherapy-induced cell death by entering stemness and quiescence associated with the c-Yes/YAP axis. Clin. Cancer Res. 2014, 20, 837-846. [CrossRef] [PubMed]

30. He, C.; Mao, D.; Hua, G.; Lv, X.; Chen, X.; Angeletti, P.C.; Dong, J.; Remmenga, S.W.; Rodabaugh, K.J.; Zhou, J.; et al. The Hippo/YAP pathway interacts with EGFR signaling and HPV oncoproteins to regulate cervical cancer progression. EMBO Mol. Med. 2015, 7, 1426-1449. [CrossRef] [PubMed]

31. Hua, G.; Lv, X.; He, C.; Remmenga, S.W.; Rodabough, K.J.; Dong, J.; Yang, L.; Lele, S.M.; Yang, P.; Zhou, J.; et al. YAP induces high-grade serous carcinoma in fallopian tube secretory epithelial cells. Oncogene 2016, 35, 2247-2265. [CrossRef] [PubMed]

32. Zhao, J.; Li, X.; Yang, Y.; Zhu, D.; Zhang, C.; Liu, D.; Wu, K.; Zhao, S. Effect of YAP1 silencing on esophageal cancer. Onco Targets Ther. 2016, 9, 3137-3146. [CrossRef] [PubMed]

33. Lin, L.; Sabnis, A.J.; Chan, E.; Olivas, V.; Cade, L.; Pazarentzos, E.; Asthana, S.; Neel, D.; Yan, J.J.; Lu, X.; et al. The Hippo effector YAP promotes resistance to RAF- and MEK-targeted cancer therapies. Nat. Genet. 2015, 47, 250-256. [CrossRef] [PubMed]

34. Zhou, Z.; Zhu, J.S.; Gao, C.P.; Li, L.P.; Zhou, C.; Wang, H.; Liu, X.G. siRNA targeting YAP gene inhibits gastric carcinoma growth and tumor metastasis in SCID mice. Oncol. Lett. 2016, 11, 2806-2814. [CrossRef] [PubMed]

35. Zhou, Z.; Zhu, J.S.; Xu, Z.P.; Zhang, Q. Lentiviral vector-mediated siRNA knockdown of the YAP gene inhibits growth and induces apoptosis in the SGC7901 gastric cancer cell line. Mol. Med. Rep. 2011, 4, 1075-1082. [CrossRef] [PubMed]

36. Tschaharganeh, D.F.; Chen, X.; Latzko, P.; Malz, M.; Gaida, M.M.; Felix, K.; Ladu, S.; Singer, S.; Pinna, F.; Gretz, N.; et al. Yes-associated protein up-regulates Jagged-1 and activates the Notch pathway in human hepatocellular carcinoma. Gastroenterology 2013, 144, 1530-1542. [CrossRef] [PubMed]

37. Tian, Y.; Tang, B.; Wang, C.; Sun, D.; Zhang, R.; Luo, N.; Han, Z.; Liang, R.; Gao, Z.; Wang, L. Metformin mediates resensitivity to 5 -fluorouracil in hepatocellular carcinoma via the suppression of YAP. Oncotarget 2016, 7, 46230-46241. [CrossRef] [PubMed]

38. Wang, X.; Wu, B.; Zhong, Z. Downregulation of YAP inhibits proliferation, invasion and increases cisplatin sensitivity in human hepatocellular carcinoma cells. Oncol. Lett. 2018, 16, 585-593. [CrossRef] [PubMed] 
39. Zhou, X.; Su, J.; Feng, S.; Wang, L.; Yin, X.; Yan, J.; Wang, Z. Antitumor activity of curcumin is involved in down-regulation of YAP/TAZ expression in pancreatic cancer cells. Oncotarget 2016, 7, 79076-79088. [CrossRef] [PubMed]

40. Jiang, Z.; Chen, X.; Chen, K.; Sun, L.; Gao, L.; Zhou, C.; Lei, M.; Duan, W.; Wang, Z.; Ma, Q.; et al. YAP Inhibition by Resveratrol via Activation of AMPK Enhances the Sensitivity of Pancreatic Cancer Cells to Gemcitabine. Nutrients 2016, 8. [CrossRef] [PubMed]

41. Diep, C.H.; Zucker, K.M.; Hostetter, G.; Watanabe, A.; Hu, C.; Munoz, R.M.; Von Hoff, D.D.; Han, H. Down-regulation of Yes Associated Protein 1 expression reduces cell proliferation and clonogenicity of pancreatic cancer cells. PLoS ONE 2012, 7, e32783. [CrossRef] [PubMed]

42. Wang, X.; Sun, D.; Tai, J.; Chen, S.; Yu, M.; Ren, D.; Wang, L. TFAP2C promotes stemness and chemotherapeutic resistance in colorectal cancer via inactivating hippo signaling pathway. J. Exp. Clin. Cancer Res. 2018, 37, 27. [CrossRef] [PubMed]

43. Li, H.; He, F.; Zhao, X.; Zhang, Y.; Chu, X.; Hua, C.; Qu, Y.; Duan, Y.; Ming, L. YAP Inhibits the Apoptosis and Migration of Human Rectal Cancer Cells via Suppression of JNK-Drp1-Mitochondrial Fission-HtrA2/Omi Pathways. Cell. Physiol. Biochem. 2017, 44, 2073-2089. [CrossRef] [PubMed]

44. Ma, K.; Xu, Q.; Wang, S.; Zhang, W.; Liu, M.; Liang, S.; Zhu, H.; Xu, N. Nuclear accumulation of Yes-Associated Protein (YAP) maintains the survival of doxorubicin-induced senescent cells by promoting survivin expression. Cancer Lett. 2016, 375, 84-91. [CrossRef] [PubMed]

45. Li, K.; Guo, J.; Wu, Y.; Jin, D.; Jiang, H.; Liu, C.; Qin, C. Suppression of YAP by DDP disrupts colon tumor progression. Oncol. Rep. 2018, 39, 2114-2126. [CrossRef] [PubMed]

46. Oku, Y.; Nishiya, N.; Sugiyama, S.; Sato, H.; Uehara, Y. Sensitisation of Cancer Cells to MLN8237, an Aurora-A Inhibitor, by YAP/TAZ Inactivation. Anticancer Res. 2018, 38, 3471-3476. [CrossRef] [PubMed]

47. Sheng, X.; Li, W.B.; Wang, D.L.; Chen, K.H.; Cao, J.J.; Luo, Z.; He, J.; Li, M.C.; Liu, W.J.; Yu, C. YAP is closely correlated with castration-resistant prostate cancer, and downregulation of YAP reduces proliferation and induces apoptosis of PC-3 cells. Mol. Med. Rep. 2015, 12, 4867-4876. [CrossRef] [PubMed]

48. Slemmons, K.K.; Crose, L.E.; Rudzinski, E.; Bentley, R.C.; Linardic, C.M. Role of the YAP Oncoprotein in Priming Ras-Driven Rhabdomyosarcoma. PLoS ONE 2015, 10, e0140781. [CrossRef] [PubMed]

49. Ma, L.; Wang, J.; Lin, J.; Pan, Q.; Yu, Y.; Sun, F. Cluster of differentiation 166 (CD166) regulated by phosphatidylinositide 3-Kinase (PI3K)/AKT signaling to exert its anti-apoptotic role via yes-associated protein (YAP) in liver cancer. J. Biol. Chem. 2014, 289, 6921-6933. [CrossRef] [PubMed]

50. Simile, M.M.; Latte, G.; Demartis, M.I.; Brozzetti, S.; Calvisi, D.F.; Porcu, A.; Feo, C.F.; Seddaiu, M.A.; Daino, L.; Berasain, C.; et al. Post-translational deregulation of YAP1 is genetically controlled in rat liver cancer and determines the fate and stem-like behavior of the human disease. Oncotarget 2016, 7, 49194-49216. [CrossRef] [PubMed]

51. Li, Y.; Li, L.; Zhu, M.; Ye, L.; Yang, Q. Upregulation of Yes-associated protein and transcriptional co-activator with PDZ-binding motif influences the behavior of LOVO human colon adenocarcinoma cells. Exp. Ther. Med. 2017, 14, 3831-3835. [CrossRef] [PubMed]

52. Wang, Y.; Dong, Q.; Zhang, Q.; Li, Z.; Wang, E.; Qiu, X. Overexpression of yes-associated protein contributes to progression and poor prognosis of non-small-cell lung cancer. Cancer Sci. 2010, 101, 1279-1285. [CrossRef] [PubMed]

53. Moon, S.; Yeon Park, S.; Woo Park, H. Regulation of the Hippo pathway in cancer biology. Cell. Mol. Life Sci. 2018, 75, 2303-2319. [CrossRef] [PubMed]

54. Liu, Z.; Zeng, W.; Wang, S.; Zhao, X.; Guo, Y.; Yu, P.; Yin, X.; Liu, C.; Huang, T. A potential role for the Hippo pathway protein, YAP, in controlling proliferation, cell cycle progression, and autophagy in BCPAP and KI thyroid papillary carcinoma cells. Am. J. Transl. Res. 2017, 9, 3212-3223. [PubMed]

55. Hoffman, B.; Liebermann, D.A. Apoptotic signaling by c-MYC. Oncogene 2008, 27, 6462-6472. [CrossRef] [PubMed]

56. Zhao, B.; Ye, X.; Yu, J.; Li, L.; Li, W.; Li, S.; Yu, J.; Lin, J.D.; Wang, C.Y.; Chinnaiyan, A.M.; et al. TEAD mediates YAP-dependent gene induction and growth control. Genes Dev. 2008, 22, 1962-1971. [CrossRef] [PubMed]

57. Wu, S.; Liu, Y.; Zheng, Y.; Dong, J.; Pan, D. The TEAD/TEF family protein Scalloped mediates transcriptional output of the Hippo growth-regulatory pathway. Dev. Cell. 2008, 14, 388-398. [CrossRef] [PubMed] 
58. Xiao, L.; Shi, X.Y.; Zhang, Y.; Zhu, Y.; Zhu, L.; Tian, W.; Zhu, B.K.; Wei, Z.L. YAP induces cisplatin resistance through activation of autophagy in human ovarian carcinoma cells. Onco Targets Ther. 2016, 9, 1105-1114. [CrossRef] [PubMed]

59. Yan, H.; Qiu, C.; Sun, W.; Gu, M.; Xiao, F.; Zou, J.; Zhang, L. Yap regulates gastric cancer survival and migration via SIRT1/Mfn2/mitophagy. Oncol. Rep. 2018, 39, 1671-1681. [CrossRef] [PubMed]

60. Song, Q.; Mao, B.; Cheng, J.; Gao, Y.; Jiang, K.; Chen, J.; Yuan, Z.; Meng, S. YAP enhances autophagic flux to promote breast cancer cell survival in response to nutrient deprivation. PLoS ONE 2015, 10, e0120790. [CrossRef] [PubMed]

61. Strano, S.; Munarriz, E.; Rossi, M.; Castagnoli, L.; Shaul, Y.; Sacchi, A.; Oren, M.; Sudol, M.; Cesareni, G.; Blandino, G. Physical interaction with Yes-associated protein enhances p73 transcriptional activity. J. Biol. Chem. 2001, 276, 15164-15173. [CrossRef] [PubMed]

62. Levy, D.; Adamovich, Y.; Reuven, N.; Shaul, Y. Yap1 phosphorylation by c-Abl is a critical step in selective activation of proapoptotic genes in response to DNA damage. Mol. Cell 2008, 29, 350-361. [CrossRef] [PubMed]

63. de Leon, N.; Valdivieso, M.H. The long life of an endocytic patch that misses AP-2. Curr. Genet. 2016, 62, 765-770. [CrossRef] [PubMed]

64. Cao, Z.; Carey, T.S.; Ganguly, A.; Wilson, C.A.; Paul, S.; Knott, J.G. Transcription factor AP-2gamma induces early $\mathrm{Cdx} 2$ expression and represses HIPPO signaling to specify the trophectoderm lineage. Development 2015, 142, 1606-1615. [CrossRef] [PubMed]

65. Kono, K.; Tamashiro, D.A.; Alarcon, V.B. Inhibition of RHO-ROCK signaling enhances ICM and suppresses TE characteristics through activation of Hippo signaling in the mouse blastocyst. Dev. Biol. 2014, 394, 142-155. [CrossRef] [PubMed]

66. Bedford, M.T.; Chan, D.C.; Leder, P. FBP WW domains and the Abl SH3 domain bind to a specific class of proline-rich ligands. EMBO J. 1997, 16, 2376-2383. [CrossRef] [PubMed]

67. Liu, W.; Wu, J.; Xiao, L.; Bai, Y.; Qu, A.; Zheng, Z.; Yuan, Z. Regulation of neuronal cell death by c-Abl-Hippo/MST2 signaling pathway. PLoS ONE 2012, 7, e36562. [CrossRef] [PubMed]

68. Tang, R.; Lei, Y.; Hu, B.; Yang, J.; Fang, S.; Wang, Q.; Li, M.; Guo, L. WW domain binding protein 5 induces multidrug resistance of small cell lung cancer under the regulation of miR-335 through the Hippo pathway. Br. J. Cancer 2016, 115, 243-251. [CrossRef] [PubMed]

69. Zhou, Y.; Shan, T.; Ding, W.; Hua, Z.; Shen, Y.; Lu, Z.; Chen, B.; Dai, T. Study on mechanism about long noncoding RNA MALAT1 affecting pancreatic cancer by regulating Hippo-YAP signaling. J. Cell. Physiol. 2018, 233, 5805-5814. [CrossRef] [PubMed]

70. Grant, T.J.; Mehta, A.K.; Gupta, A.; Sharif, A.A.D.; Arora, K.S.; Deshpande, V.; Ting, D.T.; Bardeesy, N.; Ganem, N.J.; Hergovich, A.; et al. STK38L kinase ablation promotes loss of cell viability in a subset of KRAS-dependent pancreatic cancer cell lines. Oncotarget 2017, 8, 78556-78572. [CrossRef] [PubMed]

71. Liu, Y.; Lu, J.; Zhang, Z.; Zhu, L.; Dong, S.; Guo, G.; Li, R.; Nan, Y.; Yu, K.; Zhong, Y.; et al. Amlexanox, a selective inhibitor of IKBKE, generates anti-tumoral effects by disrupting the Hippo pathway in human glioblastoma cell lines. Cell. Death Dis. 2017, 8, e3022. [CrossRef] [PubMed]

72. Lin, M.T.; Chang, C.C.; Chen, S.T.; Chang, H.L.; Su, J.L.; Chau, Y.P.; Kuo, M.L. Cyr61 expression confers resistance to apoptosis in breast cancer MCF-7 cells by a mechanism of NF-kappaB-dependent XIAP up-regulation. J. Biol. Chem. 2004, 279, 24015-24023. [CrossRef] [PubMed]

73. Ho, K.C.; Zhou, Z.; She, Y.M.; Chun, A.; Cyr, T.D.; Yang, X. Itch E3 ubiquitin ligase regulates large tumor suppressor 1 stability [corrected]. Proc. Natl. Acad. Sci. USA 2011, 108, 4870-4875. [CrossRef] [PubMed]

74. Guo, Q.; Wang, J.; Cao, Z.; Tang, Y.; Feng, C.; Huang, F. Interaction of S100A1 with LATS1 promotes cell growth through regulation of the Hippo pathway in hepatocellular carcinoma. Int. J. Oncol. 2018, 53, 592-602. [CrossRef] [PubMed]

75. Das Thakur, M.; Feng, Y.; Jagannathan, R.; Seppa, M.J.; Skeath, J.B.; Longmore, G.D. Ajuba LIM proteins are negative regulators of the Hippo signaling pathway. Curr. Biol. 2010, 20, 657-662. [CrossRef] [PubMed]

76. Bi, L.; Ma, F.; Tian, R.; Zhou, Y.; Lan, W.; Song, Q.; Cheng, X. AJUBA increases the cisplatin resistance through hippo pathway in cervical cancer. Gene 2018, 644, 148-154. [CrossRef] [PubMed]

77. Ifere, G.O.; Ananaba, G.A. Prostate cancer gene expression marker 1 (PCGEM1): A patented prostate- specific non-coding gene and regulator of prostate cancer progression. Recent Pat. DNA Gene Seq. 2009, 3, 151-163. [CrossRef] [PubMed] 
78. Chen, S.; Wang, L.L.; Sun, K.X.; Liu, Y.; Guan, X.; Zong, Z.H.; Zhao, Y. LncRNA PCGEM1 Induces Ovarian Carcinoma Tumorigenesis and Progression Through RhoA Pathway. Cell. Physiol. Biochem. 2018, 47, 1578-1588. [CrossRef] [PubMed]

79. Kim, J.G.; Islam, R.; Cho, J.Y.; Jeong, H.; Cap, K.C.; Park, Y.; Hossain, A.J.; Park, J.B. Regulation of RhoA GTPase and various transcription factors in the RhoA pathway. J. Cell. Physiol. 2018, 233, 6381-6392. [CrossRef] [PubMed]

80. Mayr, B.; Montminy, M. Transcriptional regulation by the phosphorylation-dependent factor CREB. Nat. Rev. Mol. Cell Biol. 2001, 2, 599-609. [CrossRef] [PubMed]

81. Wang, J.; Ma, L.; Weng, W.; Qiao, Y.; Zhang, Y.; He, J.; Wang, H.; Xiao, W.; Li, L.; Chu, Q.; et al. Mutual interaction between YAP and CREB promotes tumorigenesis in liver cancer. Hepatology 2013, 58, 1011-1020. [CrossRef] [PubMed]

82. Hirata, K.; Takakura, Y.; Shibazaki, M.; Morii, M.; Honda, T.; Oshima, M.; Aoyama, K.; Iwama, A.; Nakayama, Y.; Takano, H.; et al. Forkhead box protein A1 confers resistance to transforming growth factor-beta-induced apoptosis in breast cancer cells through inhibition of Smad3 nuclear translocation. J. Cell. Biochem. 2018. [CrossRef] [PubMed]

83. Wang, L.L.; Xiu, Y.L.; Chen, X.; Sun, K.X.; Chen, S.; Wu, D.D.; Liu, B.L.; Zhao, Y. The transcription factor FOXA1 induces epithelial ovarian cancer tumorigenesis and progression. Tumour Biol. 2017, 39. [CrossRef] [PubMed]

84. Ren, H.; Zhang, P.; Tang, Y.; Wu, M.; Zhang, W. Forkhead box protein A1 is a prognostic predictor and promotes tumor growth of gastric cancer. Onco Targets Ther. 2015, 8, 3029-3039. [CrossRef] [PubMed]

85. Ma, W.; Jiang, J.; Li, M.; Wang, H.; Zhang, H.; He, X.; Huang, L.; Zhou, Q. The clinical significance of forkhead box protein A1 and its role in colorectal cancer. Mol. Med. Rep. 2016, 14, 2625-2631. [CrossRef] [PubMed]

86. Yu, W.; Qiao, Y.; Tang, X.; Ma, L.; Wang, Y.; Zhang, X.; Weng, W.; Pan, Q.; Yu, Y.; Sun, F.; et al. Tumor suppressor long non-coding RNA, MT1DP is negatively regulated by YAP and Runx2 to inhibit FoxA1 in liver cancer cells. Cell Signal. 2014, 26, 2961-2968. [CrossRef] [PubMed]

87. Jimenez, A.P.; Traum, A.; Boettger, T.; Hackstein, H.; Richter, A.M.; Dammann, R.H. The tumor suppressor RASSF1A induces the YAP1 target gene ANKRD1 that is epigenetically inactivated in human cancers and inhibits tumor growth. Oncotarget 2017, 8, 88437-88452. [CrossRef] [PubMed]

88. Yee, K.S.; Grochola, L.; Hamilton, G.; Grawenda, A.; Bond, E.E.; Taubert, H.; Wurl, P.; Bond, G.L.; O’Neill, E. A RASSF1A polymorphism restricts $\mathrm{p} 53 / \mathrm{p} 73$ activation and associates with poor survival and accelerated age of onset of soft tissue sarcoma. Cancer Res. 2012, 72, 2206-2217. [CrossRef] [PubMed]

89. Donninger, H.; Clark, J.A.; Monaghan, M.K.; Schmidt, M.L.; Vos, M.; Clark, G.J. Cell cycle restriction is more important than apoptosis induction for RASSF1A protein tumor suppression. J. Biol. Chem. 2014, 289, 31287-31295. [CrossRef] [PubMed]

90. Dinkel, A.; Warnatz, K.; Ledermann, B.; Rolink, A.; Zipfel, P.F.; Burki, K.; Eibel, H. The transcription factor early growth response 1 (Egr-1) advances differentiation of pre-B and immature B cells. J. Exp. Med. 1998, 188, 2215-2224. [CrossRef] [PubMed]

91. Zagurovskaya, M.; Shareef, M.M.; Das, A.; Reeves, A.; Gupta, S.; Sudol, M.; Bedford, M.T.; Prichard, J.; Mohiuddin, M.; Ahmed, M.M. EGR-1 forms a complex with YAP-1 and upregulates Bax expression in irradiated prostate carcinoma cells. Oncogene 2009, 28, 1121-1131. [CrossRef] [PubMed]

92. Baek, S.J.; Kim, J.S.; Moore, S.M.; Lee, S.H.; Martinez, J.; Eling, T.E. Cyclooxygenase inhibitors induce the expression of the tumor suppressor gene EGR-1, which results in the up-regulation of NAG-1, an antitumorigenic protein. Mol. Pharmacol. 2005, 67, 356-364. [CrossRef] [PubMed]

93. Calogero, A.; Arcella, A.; De Gregorio, G.; Porcellini, A.; Mercola, D.; Liu, C.; Lombari, V.; Zani, M.; Giannini, G.; Gagliardi, F.M.; et al. The early growth response gene EGR-1 behaves as a suppressor gene that is down-regulated independent of $\mathrm{ARF} / \mathrm{Mdm} 2$ but not p53 alterations in fresh human gliomas. Clin. Cancer Res. 2001, 7, 2788-2796. [PubMed]

94. Liu, C.; Calogero, A.; Ragona, G.; Adamson, E.; Mercola, D. EGR-1, the reluctant suppression factor: EGR-1 is known to function in the regulation of growth, differentiation, and also has significant tumor suppressor activity and a mechanism involving the induction of TGF-beta1 is postulated to account for this suppressor activity. Crit. Rev. Oncog. 1996, 7, 101-125. [PubMed]

95. Gitenay, D.; Baron, V.T. Is EGR1 a potential target for prostate cancer therapy? Future Oncol. 2009, 5, $993-1003$. [CrossRef] [PubMed] 
96. Virolle, T.; Krones-Herzig, A.; Baron, V.; De Gregorio, G.; Adamson, E.D.; Mercola, D. Egr1 promotes growth and survival of prostate cancer cells. Identification of novel Egr1 target genes. J. Biol. Chem. 2003, 278, 11802-11810. [CrossRef] [PubMed]

97. Kim, M.; Kim, M.; Lee, S.; Kuninaka, S.; Saya, H.; Lee, H.; Lee, S.; Lim, D.S. cAMP/PKA signalling reinforces the LATS-YAP pathway to fully suppress YAP in response to actin cytoskeletal changes. EMBO J. 2013, 32, 1543-1555. [CrossRef] [PubMed]

98. Zhang, K.; Hu, Z.; Qi, H.; Shi, Z.; Chang, Y.; Yao, Q.; Cui, H.; Zheng, L.; Han, Y.; Han, X.; et al. G-protein-coupled receptors mediate omega-3 PUFAs-inhibited colorectal cancer by activating the Hippo pathway. Oncotarget 2016, 7, 58315-58330. [CrossRef] [PubMed]

99. Zhao, B.; Li, L.; Tumaneng, K.; Wang, C.Y.; Guan, K.L. A coordinated phosphorylation by Lats and CK1 regulates YAP stability through SCF(beta-TRCP). Genes Dev. 2010, 24, 72-85. [CrossRef] [PubMed]

100. He, Z.; Zhao, T.T.; Jin, F.; Li, J.G.; Xu, Y.Y.; Dong, H.T.; Liu, Q.; Xing, P.; Zhu, G.L.; Xu, H.; et al. Downregulation of RASSF6 promotes breast cancer growth and chemoresistance through regulation of Hippo signaling. Biochem. Biophys. Res. Commun. 2018, 503, 2340-2347. [CrossRef] [PubMed]

101. Slavotinek, A.M. The Family of Crumbs Genes and Human Disease. Mol. Syndromol. 2016, 7, $274-281$. [CrossRef] [PubMed]

102. Mao, X.; Li, P.; Wang, Y.; Liang, Z.; Liu, J.; Li, J.; Jiang, Y.; Bao, G.; Li, L.; Zhu, B.; et al. CRB3 regulates contact inhibition by activating the Hippo pathway in mammary epithelial cells. Cell. Death Dis. 2017, 8, e2546. [CrossRef] [PubMed]

103. Szymaniak, A.D.; Mahoney, J.E.; Cardoso, W.V.; Varelas, X. Crumbs3-Mediated Polarity Directs Airway Epithelial Cell Fate through the Hippo Pathway Effector Yap. Dev. Cell. 2015, 34, 283-296. [CrossRef] [PubMed]

104. Mo, J.S.; Meng, Z.; Kim, Y.C.; Park, H.W.; Hansen, C.G.; Kim, S.; Lim, D.S.; Guan, K.L. Cellular energy stress induces AMPK-mediated regulation of YAP and the Hippo pathway. Nat. Cell. Biol. 2015, 17, 500-510. [CrossRef] [PubMed]

105. Bennewith, K.L.; Huang, X.; Ham, C.M.; Graves, E.E.; Erler, J.T.; Kambham, N.; Feazell, J.; Yang, G.P.; Koong, A.; Giaccia, A.J. The role of tumor cell-derived connective tissue growth factor (CTGF/CCN2) in pancreatic tumor growth. Cancer Res. 2009, 69, 775-784. [CrossRef] [PubMed]

106. Inuzuka, H.; Shaik, S.; Onoyama, I.; Gao, D.; Tseng, A.; Maser, R.S.; Zhai, B.; Wan, L.; Gutierrez, A.; Lau, A.W.; et al. SCF(FBW7) regulates cellular apoptosis by targeting MCL1 for ubiquitylation and destruction. Nature 2011, 471, 104-109. [CrossRef] [PubMed]

107. Tu, K.; Yang, W.; Li, C.; Zheng, X.; Lu, Z.; Guo, C.; Yao, Y.; Liu, Q. Fbxw7 is an independent prognostic marker and induces apoptosis and growth arrest by regulating YAP abundance in hepatocellular carcinoma. Mol. Cancer 2014, 13, 110. [CrossRef] [PubMed]

108. Lei, C.J.; Yao, C.; Li, D.K.; Long, Z.X.; Li, Y.; Tao, D.; Liou, Y.P.; Zhang, J.Z.; Liu, N. Effect of co-transfection of miR-520c-3p and miR-132 on proliferation and apoptosis of hepatocellular carcinoma Huh7. Asian Pac. J. Trop. Med. 2016, 9, 898-902. [CrossRef] [PubMed]

109. Zhu, Y.; Shi, L.Y.; Lei, Y.M.; Bao, Y.H.; Li, Z.Y.; Ding, F.; Zhu, G.T.; Wang, Q.Q.; Huang, C.X. Radiosensitization effect of hsa-miR-138-2-3p on human laryngeal cancer stem cells. PeerJ 2017, 5, e3233. [CrossRef] [PubMed]

110. Su, X.; Chakravarti, D.; Flores, E.R. p63 steps into the limelight: Crucial roles in the suppression of tumorigenesis and metastasis. Nat. Rev. Cancer 2013, 13, 136-143. [CrossRef] [PubMed]

111. Ehsanian, R.; Brown, M.; Lu, H.; Yang, X.P.; Pattatheyil, A.; Yan, B.; Duggal, P.; Chuang, R.; Doondeea, J.; Feller, S.; et al. YAP dysregulation by phosphorylation or DeltaNp63-mediated gene repression promotes proliferation, survival and migration in head and neck cancer subsets. Oncogene 2010, 29, 6160-6171. [CrossRef] [PubMed]

112. Li, Y.; Kong, F.; Shao, Q.; Wang, R.; Hu, E.; Liu, J.; Jin, C.; He, D.; Xiao, X. YAP Expression and Activity Are Suppressed by S100A7 via p65/NFkappaB-mediated Repression of DeltaNp63. Mol. Cancer Res. 2017, 15, 1752-1763. [CrossRef] [PubMed]

113. Urner, F.; Sakkas, D. Protein phosphorylation in mammalian spermatozoa. Reproduction 2003, 125, 17-26. [CrossRef] [PubMed]

114. Basu, S.; Totty, N.F.; Irwin, M.S.; Sudol, M.; Downward, J. Akt phosphorylates the Yes-associated protein, YAP, to induce interaction with 14-3-3 and attenuation of p73-mediated apoptosis. Mol. Cell 2003, 11, 11-23. [CrossRef] 
115. Yimlamai, D.; Fowl, B.H.; Camargo, F.D. Emerging evidence on the role of the Hippo/YAP pathway in liver physiology and cancer. J. Hepatol. 2015, 63, 1491-1501. [CrossRef] [PubMed]

116. Jin, L.; Chen, Y.; Mu, X.; Lian, Q.; Deng, H.; Ge, R. Phosphoproteomic analysis of gossypol-induced apoptosis in ovarian cancer cell line, HOC1a. Biomed. Res. Int. 2014, 2014, 123482. [CrossRef] [PubMed]

117. Yu, S.; Cai, X.; Wu, C.; Liu, Y.; Zhang, J.; Gong, X.; Wang, X.; Wu, X.; Zhu, T.; Mo, L.; et al. Targeting HSP90-HDAC6 Regulating Network Implicates Precision Treatment of Breast Cancer. Int. J. Biol. Sci. 2017, 13, 505-517. [CrossRef] [PubMed]

118. Jin, D.; Wu, Y.; Shao, C.; Gao, Y.; Wang, D.; Guo, J. Norcantharidin reverses cisplatin resistance and inhibits the epithelial mesenchymal transition of human nonsmall lung cancer cells by regulating the YAP pathway. Oncol. Rep. 2018, 40, 609-620. [CrossRef] [PubMed]

119. Guo, J.; Wu, Y.; Yang, L.; Du, J.; Gong, K.; Chen, W.; Dai, J.; Li, X.; Xi, S. Repression of YAP by NCTD disrupts NSCLC progression. Oncotarget 2017, 8, 2307-2319. [CrossRef] [PubMed]

120. Zhang, H.T.; Gui, T.; Sang, Y.; Yang, J.; Li, Y.H.; Liang, G.H.; Li, T.; He, Q.Y.; Zha, Z.G. The BET Bromodomain Inhibitor JQ1 Suppresses Chondrosarcoma Cell Growth via Regulation of YAP/p21/c-Myc Signaling. J. Cell. Biochem. 2017, 118, 2182-2192. [CrossRef] [PubMed]

121. Toden, S.; Ravindranathan, P.; Gu, J.; Cardenas, J.; Yuchang, M.; Goel, A. Oligomeric proanthocyanidins (OPCs) target cancer stem-like cells and suppress tumor organoid formation in colorectal cancer. Sci. Rep. 2018, 8, 3335. [CrossRef] [PubMed]

122. Zheng, H.X.; Wu, L.N.; Xiao, H.; Du, Q.; Liang, J.F. Inhibitory effects of dobutamine on human gastric adenocarcinoma. World J. Gastroenterol. 2014, 20, 17092-17099. [CrossRef] [PubMed]

123. Shan, L.; Li, Y.; Jiang, H.; Tao, Y.; Qian, Z.; Li, L.; Cai, F.; Ma, L.; Yu, Y. Huaier Restrains Proliferative and Migratory Potential of Hepatocellular Carcinoma Cells Partially Through Decreased Yes-Associated Protein 1. J. Cancer 2017, 8, 4087-4097. [CrossRef] [PubMed]

124. Hou, L.; Chen, L.; Fang, L. Scutellarin Inhibits Proliferation, Invasion, and Tumorigenicity in Human Breast Cancer Cells by Regulating HIPPO-YAP Signaling Pathway. Med. Sci. Monit. 2017, 23, 5130-5138. [CrossRef] [PubMed]

125. Xu, G.; Wang, J.; Wu, F.; Wang, N.; Zhou, W.; Wang, Q.; Pan, W.; Ao, G.; Yang, J. YAP and 14-3-3gamma are involved in HS-OA-induced growth inhibition of hepatocellular carcinoma cells: A novel mechanism for hydrogen sulfide releasing oleanolic acid. Oncotarget 2016, 7, 52150-52165. [CrossRef] [PubMed]

126. Wei, H.; Wang, F.; Wang, Y.; Li, T.; Xiu, P.; Zhong, J.; Sun, X.; Li, J. Verteporfin suppresses cell survival, angiogenesis and vasculogenic mimicry of pancreatic ductal adenocarcinoma via disrupting the YAP-TEAD complex. Cancer Sci. 2017, 108, 478-487. [CrossRef] [PubMed]

127. Ma, Y.W.; Liu, Y.Z.; Pan, J.X. Verteporfin induces apoptosis and eliminates cancer stem-like cells in uveal melanoma in the absence of light activation. Am. J. Cancer Res. 2016, 6, 2816-2830. [PubMed]

128. Pan, W.; Wang, Q.; Zhang, Y.; Zhang, N.; Qin, J.; Li, W.; Wang, J.; Wu, F.; Cao, L.; Xu, G. Verteporfin can Reverse the Paclitaxel Resistance Induced by YAP Over-Expression in HCT-8/T Cells without Photoactivation through Inhibiting YAP Expression. Cell. Physiol. Biochem. 2016, 39, 481-490. [CrossRef] [PubMed]

129. Song, S.; Xie, M.; Scott, A.W.; Jin, J.; Ma, L.; Dong, X.; Skinner, H.D.; Johnson, R.L.; Ding, S.; Ajani, J.A. A Novel YAP1 Inhibitor Targets CSC-Enriched Radiation-Resistant Cells and Exerts Strong Antitumor Activity in Esophageal Adenocarcinoma. Mol. Cancer Ther. 2018, 17, 443-454. [CrossRef] [PubMed]

130. Zhao, Y.; Zhou, W.; Xue, L.; Zhang, W.; Zhan, Q. Nicotine activates YAP1 through nAChRs mediated signaling in esophageal squamous cell cancer (ESCC). PLoS ONE 2014, 9, e90836. [CrossRef] [PubMed]

131. Maruyama, J.; Inami, K.; Michishita, F.; Jiang, X.; Iwasa, H.; Nakagawa, K.; Ishigami-Yuasa, M.; Kagechika, H.; Miyamura, N.; Hirayama, J.; et al. Novel YAP1 activator, identified by transcription-based functional screen, limits multiple myeloma growth. Mol. Cancer Res. 2018, 16, 197-211. [CrossRef] [PubMed]

132. Xu, Y.; Zhao, Y.; Xu, Y.; Guan, Y.; Zhang, X.; Chen, Y.; Wu, Q.; Zhu, G.; Chen, Y.; Sun, F.; et al. Blocking inhibition to YAP by ActinomycinD enhances anti-tumor efficacy of Corosolic acid in treating liver cancer. Cell Signal. 2017, 29, 209-217. [CrossRef] [PubMed]

133. Tiwary, R.; Yu, W.; Sanders, B.G.; Kline, K. alpha-TEA cooperates with chemotherapeutic agents to induce apoptosis of p53 mutant, triple-negative human breast cancer cells via activating p73. Breast Cancer Res. 2011, 13, R1. [CrossRef] [PubMed] 
134. Yang, C.; Tan, J.; Zhu, J.; Wang, S.; Wei, G. YAP promotes tumorigenesis and cisplatin resistance in neuroblastoma. Oncotarget 2017, 8, 37154-37163. [CrossRef] [PubMed]

135. Ciamporcero, E.; Shen, H.; Ramakrishnan, S.; Yu Ku, S.; Chintala, S.; Shen, L.; Adelaiye, R.; Miles, K.M.; Ullio, C.; Pizzimenti, S.; et al. YAP activation protects urothelial cell carcinoma from treatment-induced DNA damage. Oncogene 2016, 35, 1541-1553. [CrossRef] [PubMed]

136. Gujral, T.S.; Kirschner, M.W. Hippo pathway mediates resistance to cytotoxic drugs. Proc. Natl. Acad. Sci. USA 2017, 114, e3729-e3738. [CrossRef] [PubMed] 